Bell DNF \& Blanchflower DG, The Lack of Wage Growth and the Falling NAIRU National Institute Economic Review, 245 (1), pp. R40-R55. Copyright (C) The Author(s) 2018. Reprinted by permission of SAGE Publications.

\title{
The Lack of Wage Growth and the Falling NAIRU
}

\author{
David N.F. Bell \\ Division of Economics, Stirling Management School, University of Stirling, \\ IZA and CPC \\ and \\ David G. Blanchflower \\ Bruce V. Rauner Professor of Economics, \\ Department of Economics, Dartmouth College, \\ Division of Economics, Stirling Management School, University of Stirling, \\ IZA, Bloomberg and NBER
}

We thank Doug Staiger, Gertjan Vlieghe, Malhar Nabar and Andy Levin for helpful comments and suggestions.

$17^{\text {th }}$ June 2018 
There remains a puzzle around the world over why wage growth is so benign given the low levels of unemployment. In the US, the unemployment rate at the time of writing is $4.1 \%$ and in the UK $4.3 \%$. The wage growth of production and non-supervisory workers in the US, which accounts for $82 \%$ of private sector workers, has remained flat at around $2.5 \%$ for twenty-for months in a row as the unemployment rate fell from $4.9 \%$ to $3.8 \%$. In the UK wage growth in April 2018 was $2.5 \%$.

There has also been little wage growth across the OECD. Table 1 reports real wage growth in the period 2000-2008 and then from 2008 through 2016 using data from the OECD on annual earnings in local currencies at 2016 prices. Real wage growth across the OECD has been benign in the years since 2008 and much less than in the period 2000-2008. Over this eight-year period only France, Germany; Iceland; Norway and Sweden saw average growth rates of above 1\%. In the UK real wages grew not at all and they fell in Greece, Italy and Portugal. The highest growth rate was $11 \%$ in Sweden, compared with the highest in the previous period of $27 \%$ in Norway.

The weakness of wage growth has continued to be a surprise to policymakers. At the press conference following the rate increase decision at the FOMC meeting on June $13^{\text {th }} 2018$ chair Jerome Powell said "we had anticipated and many people have anticipated that wages -- that in a world where we're hearing lots and lots about labor shortages -- everywhere we go now, we hear about labor shortages, but where is the wage reaction? So, it's a bit of a puzzle. I wouldn't say it's a mystery, but it's a bit of a puzzle. And one of the things is, you will see pretty much people who want to get jobs -- not everybody -- but people who want to get jobs, many of them will be able to get jobs. You will see wages go up."

Hope springs eternal. The projections from the June meeting showed that the FOMC members thought that the long-run value for unemployment, its natural rate, is in the range $4.1 \%$ to $4.7 \% .^{1}$ With the unemployment rate at $3.8 \%$, there surely, according to the FOMC, should have been roaring wage pressure, and fear of a wage explosion is one of the main reasons the Fed are raising rates. The fact there is little sign of wage growth picking up is neither a puzzle nor a mystery. The FOMC appears to have underestimated the amount of labour market slack.

It is our contention in this paper that a considerable part of the explanation for the benign wage growth in the advanced world is the rise in underemployment. This is also reported in Table 1, here measured as the proportion of those who say they are involuntarily part-time as a percentage of total employment. This measure of underemployment picked up for most countries after 2008 and then turned down. However, it is notable that in Australia; Italy; New Zealand and the Netherlands the rate rose steadily over the period. With the exception of Belgium; Finland; Germany, Israel and Sweden, the 2016 rate is still above the 2007 rate. It is about the same in Japan. This contrasts with the unemployment rate, which, as noted above, for example, for the US and UK has returned to pre-recession levels. In 2016, underemployment rates on this measure were especially high in Australia (8.9\%); France (7.8\%); Spain (9.9\%) and Italy $(11.9 \%)$.

This lack of wage pressure has continued to generate consternation among policy makers, who continue to expect nominal annual wage growth to revert to pre-recession averages of $4 \%$ or higher and real wage growth nearer to $2 \%$. We start off looking at wages and wage growth in the UK and

\footnotetext{
${ }^{1}$ https://www.federalreserve.gov/monetarypolicy/files/fomcprojtabl20180613.pdf
} 
how wage growth weakness is related to the rise in underemployment. We then move on to examine wage growth in 28 OECD countries and also find that underemployment plays a significant role. We examine arguments that suggest the natural rate of unemployment, the NAIRU, has fallen sharply. We present evidence to show that the UK Phillips curve has flattened.

\section{Lack of wage growth in the UK}

Policymakers in the UK have been expecting wage growth to take off for years. For example, in the opening statement at the February 2018 press conference for the Inflation Report Bank of England Governor Carney argued

"The firming of shorter-term measures of wage growth in recent quarters, and a range of survey indicators that suggests pay growth will rise further in response to the tightening labour market, give increasing confidence that growth in wages and unit labour costs will pick up to targetconsistent rates."

Governor Carney went on to say "following a long period of consistently overestimating wage growth, the MPC has updated its view of the natural rate of unemployment. Specifically, the MPC now judges that the rate of unemployment the economy can achieve while being consistent with sustainable rates of wage growth to be around $41 / 2 \%$, down from around 5\% previously." The February 2018 Inflation report reduced it again to $4 \frac{1}{4} \%$. "Based on a range of evidence, the MPC judges that the long-term equilibrium unemployment rate is around $4 \frac{1}{4} \%$, a little lower than judged a year ago and broadly in line with the current headline rate of unemployment."

On February $21^{\text {st }}$ the Bank of England's chief economist Andy Haldane continued the hopeful theme that wages were set to rocket

"The long-awaited -- and we have been waiting for a long time -- pickup in wages is starting to take root. We get intelligence from our agents that would suggest that wage settlements this year were going to pick up, perhaps to a number with a three in front of it, rather than a two in front of it." ${ }^{2}$

In a speech on June $7^{\text {th }}, 2018$ MPC member Dave Ramsden said: "The period of unusually subdued growth in wages appears to be coming to an end." On $4^{\text {th }}$ June 2018 MPC member Silvana Tenreyro in a speech said "the labour market has continued to tighten. I am unconvinced by reports of the death of the Phillips curve, so I expect this to translate into a pickup in domestic cost pressures. Indeed, annual private-sector regular pay growth reached 3\% in March, while evidence from the distribution of wage growth also signals greater strength." On $12^{\text {th }}$ June 2018, the ONS published the latest wage data which showed that regular pay growth in April fell back to $2.5 \%$ from $3 \%$ in March. Total pay also rose by $2.5 \%$ in April, the same rate as in March 2018.

In large part the MPC has had to reduce its estimates of the natural rate of unemployment because it has continued to over-estimate wage growth. Table 2 shows the MPC's forecast for wage growth in the last seventeen inflation reports dating from February 2014 through February 2018. Each of these forecasts over-estimated wage growth and there has been little or no learning from previous

${ }^{2}$ David Goodman, 'BOE's Haldane Says U.K. Wage Growth Is Starting to Take Root' Bloomberg, $21^{\text {st }}$ February 2018. 
errors. The forecasts have been poor to say the least. Three-year ahead wage forecasts in every case were around $4 \%$, but over time the forecasts were reduced as the data showed that a $2 \%$ pay norm existed. Pay settlements have continued to suggest a pay norm over the last several years of around 2\%. Even in February 2018, the MPC is forecasting wage growth of $3 \%$ in 2018, 31/4\% in 2019 and $3 \frac{1}{2} \%$ in 2020 which seems most unlikely. The outcomes reported in the final row of the table are the averages for the year-on-year growth rates by month of AWE Total Pay. It makes little sense to focus on regular pay excluding bonuses as we are interested in how much workers are paid rather than what the payments are called; many bonuses are paid regularly.

Results from the Bank's Agents' annual pay survey are consistent with an increase in pay growth. The survey recorded an average pay settlement in the private sector of $2.6 \%$ in 2017 , higher than companies had expected in the survey a year ago. In 2018, the average private sector pay settlement was expected to be $1 / 2$ percent higher, at $3.1 \%$. With the exception of construction, average pay settlements were predicted to rise in all sectors in 2018. Respondents to the survey had reported that the main factors pushing up total labour cost growth per employee were the difficulty of recruiting and retaining staff, employer pension contributions, higher consumer price inflation and the National Living Wage.

Pay experts XPertHr also reported a rise in settlements at the start of 2018. Median pay deals in the three months to the end of January 2018 were $2.5 \%$, which marks an increase on the $2 \%$ median award recorded in every rolling quarter during 2017, and is the highest figure seen since the three months to the end of March 2014 (when pay awards were also at a median rate of 2.5\%). Maybe it will all change in 2018 and after seventeen failed attempts they will have it right this time? We doubt it.

In a recent speech Sir John Cunliffe, Deputy Governor at the Bank of England took a somewhat more dovish tone arguing that there was likely more labour market slack in the UK due to underemployment. ${ }^{3}$

"A straightforward explanation of why pay growth is subdued at very low levels of unemployment is that we are under-measuring the amount of spare capacity - or 'slack' - in the labour market. Recent trends in the world of work have meant greater (voluntary and involuntary) selfemployment and part-time employment. Measures incorporating under-employment as well as unemployment - i.e. how much more people who are in work would like to work - may give a better indication of the amount of spare capacity in the labour market. In such a world, low pay is simply telling the policy maker that there is more labour market slack than the unemployment indicators are registering, that the output gap is larger than thought and that the economy can grow at a faster rate without generating domestic inflation pressure." That seems right.

It is our contention that the MPC's failure to forecast wage growth appropriately and hence to accurately predict the natural rate of unemployment is because they have focused on unemployment and have largely ignored underemployment. We described in Bell and Blanchflower (2014) how the MPC argued in May 2014 that it was appropriate to consider the rise

\footnotetext{
${ }^{3}$ Cunliffe, J. (2017), 'The Phillips curve: lower, flatter or in hiding?', Speech given at the Oxford Economics Society, Bank of England, $14^{\text {th }}$ November.
} 
in underemployment but would only take account of half of this increase because "only around half of the present gap between actual hours and the estimate of desired hours represents labour market slack". This judgement was based on calculations presented in a speech by Martin Weale (2014) which seemed unusual given that underemployment historically had disappeared when labour markets tightened. In fact, rather than being above the unemployment rate, the underemployment rate was below the unemployment rate for the years 2001-2008 because workers wanted, in aggregate to reduce their hours, rather than increase them. Hence the Weale adjustment looks in error. The subsequent path of wage growth indicated that judgement laid to continuing overestimation of wage growth - the MPC forecast for wage growth in 2016 was $3 \frac{1}{2} \%$ and for 2017 it was $33 \% 4 \%$.

In the United States, underemployment is measured by estimating the number of part-time workers who say they are part-time for economic reasons (PTER). In Europe, the estimates of underemployment are based on the number of part-time workers who want a full-time job (PTWFT). Chart 1 reports these two measures for the UK and USA, expressed as a proportion of total employment. In both countries they rose sharply peaking at $6.7 \%$ in the US in March 2010 and at $4.8 \%$ in the UK between June and August 2013. both series declined more slowly than the respective unemployment rates, which by the end of 2017 in both countries had returned to their pre-recession levels. But not so for both underemployment series, which remained well above their starting levels. There were similar rises across other European countries. ${ }^{4}$

In previous papers, we have examined underemployment in the UK using micro-data (Bell and Blanchflower, 2011, 2013, 2015, 2018). The data used in this and the previous studies are the quarterly ONS Labour Force Surveys (LFS). In this paper, we report data for the period April 2001 to December 2017. Individuals may be included for up to five waves.

The simplest underemployment variable to construct using the LFS is the "part time-wants fulltime" (PTWFT) category which is included as one possible response for the variable ftptw. This response is used to construct the UK time series in Chart 1. We are also able to construct an overhrs (undhrs) variable for those who say they want less (more) hours at the going wage rate. Those who wish to increase (decrease) their hours have undhrs (overhrs) set to zero. If individuals express no preference to change their hours, all three variables are set to zero.

Questions over hours preferences are asked of all workers, not just of those who are PTWFT. This potentially matters because the data suggests that less than a third of aggregate desired increases in hours come from those who are PTWFT. In the US, only PTER is available from the Current Population Survey so it is not possible to measure desired increases or decreases in hours, and therefore impossible to assess the contribution of PETR to aggregate desired hours increases.

Table 3 reports the distribution of workers available in the LFS sample in the pre-recession period 2001-2008 and post-recession 2009-2017. It identifies five different types of part-time work, one of which is PTWFT, and full-time classified as under hours for those who wanted more hours and over hours for those who wanted less, along with their share of total employment. It reports the

\footnotetext{
${ }^{4}$ See 'Underemployment and potential additional labour force statistics', Eurostat, May 2017. http://ec.europa.eu/eurostat/statisticsexplained/index.php/Underemployment_and_potential_additional_labour_force_statistics
} 
number of hours individuals would like, conditional on saying they wanted to change their hours, which includes all the PTWFT, who want, on average to increase their working week by ten hours in the first period and by eleven hours in the second.

A number of points stand out.

1) There is a rise over time in the proportion of workers who are PTWFT.

2) There is a roughly equivalent fall in the proportion of full-timers.

3) The number of under hours reported is positive in all six categories and rises over time in all of them.

4) There is little or no change over time in the number of over hours.

5) Overall, only $23 \%$ of under hours in the first period and $31 \%$ in the second is accounted for by PTWFT.

6) On average the PTWFT want to increase their hours by 10 hours pre-recession and by 11 postrecession. There also are a lot more of them post-recession.

Chart 2 presents quarterly time series evidence on the Bell/Blanchflower underemployment index. It compares the unemployment rate with the underemployment rate we construct. In the prerecession period the underemployment rate is below the unemployment rate and in the years after 2008 it is above it. Why?

Chart 3 shows how that comes about. It plots aggregate under hours and aggregate over hours. The under hours series is below the over hours series before 2008, when the series cross. The over hours series starts to rise from around 2014, whereas the under hours series seems to have been rising from around 2004 and then declines in 2014. The two are quite close by 2017 Q4, with the unemployment rate and the underemployment rate at $4.6 \%$ and the underemployment rate at $4.9 \%$ (seasonally adjusted).

A number of commentators suggested that this chart shows that the underemployment slack has been used up, but Chart 4 suggests that may not be correct. In equilibrium, it may be that workers in aggregate want to reduce their hours. For the entire period 2001Q2 to 2008Q2, the number of desired hours was negative, because the numbers who wanted more hours was less than the number wanting less. This suggests there may be more labour market slack to be used up to get back to the conditions prevailing between 2002 and 2004, when the monthly unemployment rate averaged $5.1 \%$.

\section{Wages}

We now turn to examine wage determination using the LFS micro-level data for the period 20012017. This builds on earlier work estimating wage equations for the UK in Blanchflower and Oswald (1994a, b) and Blanchflower and Bryson (2010). Overall, in our LFS sample there are $6,119,687$ observations on individuals age sixteen and over of whom 3,027,991 are employees and 480,558 self-employed. We have hourly wage data on 856,366 employees across the pooled data file. We drop around 10,000 cases in the regressions due to missing values. Wages are only reported in waves 1 and 5. The self-employed do not report earnings so therefore they cannot be included in the wage analysis. 
Table 4 estimates a log hourly wage equation for employees for the period 2001-2017, and then for 2001-2008, and finally for 2009-2017. In our previous work on underemployment we have not previously estimated a wage equation with underemployment and over-employment terms. Table 4 includes both the under hours and over hours variables which are negative and positive, respectively and (highly) significantly so. If the job offers fewer hours that the employee desires, wage increases will be lower. In contrast, wages are higher in jobs where hours are longer than employees wish - a compensating wage differential. In addition, coefficients on all five categories of part-time working are significantly negative, where full-time is the excluded category. Parttimers who want extra hours are paid less than part-timers who are content with their hours. It seems that having workers in jobs where they want more hours keeps wages down as they accept lower pay, conditional on their characteristics.

In a recent paper, Hong et al (2018) estimated relationships seeking to explain wage changes in 29 advanced countries from 2000 to 2016. They augmented the unemployment rate in these relationships with measures of underemployment, arguing that headline unemployment rates are becoming less able to accurately capture labor market slack. They found that "involuntary parttime employment appears to have weakened wage growth even in economies where headline unemployment rates are now at, or below, their averages in the years leading up to the recession." In a wage change equation, the involuntary part-time employment share enters negatively and significantly in most specifications. Across all countries, on average, a 1 percentage point increase in the involuntary part-time employment share is associated with a 0.3 percentage point decline in nominal wage growth. It should be said, though, that their equations look to be miss-specified as they do not contain a lagged wage term.

The authors have very kindly shared their data with us. It comprises an unbalanced panel of 688 observations on wages, involuntary employment as a share of total employment and the unemployment rate on 28 countries. ${ }^{5}$ Table 5 reports the results of estimating wage change equations that also include a highly significant lagged wage term. Both the unemployment rate and the involuntary share variables enter significantly negative. In private communication, Malhar Nabar commented that "It doesn't surprise us that the involuntary PT is significant in your specifications - it was robust across our analysis." What is their conclusion?

It is clear that the unemployment rate fails to fully explain the level of slack prevailing in most OECD countries since the Great Recession,. But it does seem that underemployment cannot, on its own, explain low levels of wage growth. A further possibility exists, namely that there has been a structural shift in the UK economy such that the natural rate of unemployment, or the NAIRU has shifted downwards. The data seems also to support this contention. Price inflation and wage inflation both remain benign. And the UK seems to be a long way from full employment.

\footnotetext{
${ }^{5}$ Australia 1999-2016; Austria 1995-2016; Belgium 1983-2016; Canada 1976-2016; Czech Republic 1998-2016; Denmark 1983-2016; Estonia 2005-2016; Finland 1985-2016; France 1993-2016; Germany 1992-2016; Greece 19962016; Iceland 2007-2016; Ireland 1990-2016; Israel 1996-2016; Italy 1983-2016; Japan 2002-2016; Lithuania 20052016; Netherlands 1983-2016; New Zealand 1986-2016; Norway 1989-2016; Portugal 1996-2016; Slovak Republic 1994-2016; Slovenia 2005-2016; Spain 1987-2016; Sweden 1976-2016; Switzerland 1991-2016; United Kingdom 1983-2016; United States 1998-2016.
} 


\section{The natural rate of unemployment or the NAIRU in the UK has fallen}

In his 1968 address to the American Economic Association, Milton Friedman (1958) famously argued that the natural rate of unemployment can be expected to depend upon the degree of labor mobility in the economy. ${ }^{6}$ The functioning of the labor market will thus be shaped not just by long-studied factors such as the generosity of unemployment benefits and the strength of trade unions but also by the nature, and inherent flexibility and dynamism of, the housing market.

Friedman also made clear that the natural rate of unemployment is not unchanging "I do not suggest that it is immutable or unchangeable. On the contrary, many of the market characteristics that determine its level are man-made and policy-made." Friedman goes on to argue, for example, that the strength of union power and the size of the minimum wage all make the natural rate higher; their declines in recent years, then make the natural rate lower. He further suggests that improvements in labor exchanges, in availability of information about job vacancies and labor supply, all of which have been enhanced by the internet, tend to lower the natural rate. That, we contend, is what has happened. The natural rate of unemployment in advanced countries has fallen sharply since the Great Recession.

Friedman continues. "The natural rate of unemployment is such that at a lower rate of unemployment indicates that there would be an excess demand for labor that will push up wage rates. A higher level of unemployment is an indication that there is an excess supply of labor that will produce downward pressure on real wage rates." (p.8).

Then Chair of the US Federal Reserve, Janet Yellen, in a speech in September 2017 raised the possibility that indeed, the natural rate has fallen and perhaps by a lot: ${ }^{7}$

"some key assumptions underlying the baseline outlook could be wrong in ways that imply that inflation will remain low for longer than currently projected. For example, labor market conditions may not be as tight as they appear to be, and thus they may exert less upward pressure on inflation than anticipated."

\section{And later}

"The unemployment rate consistent with long-run price stability at any time is not known with certainty; we can only estimate it. The median of the longer-run unemployment rate projections submitted by FOMC participants last week is around 4-1/2 percent. But the long-run sustainable

\footnotetext{
${ }^{6}$ Friedman explained what the natural rate of unemployment is and what determines it. "The "natural rate of unemployment," in other words, is the level that would be ground out by the Walrasian system of general equilibrium equations, provided there is imbedded in them the actual structural characteristics of the labor and commodity markets, including market imperfections, stochastic variability in demands and supplies, the cost of gathering information about job vacancies and labor availabilities, the costs of mobility, and so on."

7 Janet L. Yellen, 'Inflation, uncertainty, and monetary policy, speech at the Prospects for Growth: Reassessing the Fundamentals, 59th Annual Meeting of the National Association for Business Economics, Cleveland, Ohio, September $26^{\text {th }}, 2017$.
} 
unemployment rate can drift over time because of demographic changes and other factors, some of which can be difficult to quantify--or even identify--in real time. For these and other reasons, the statistical precision of such estimates is limited, and the actual value of the sustainable rate could well be noticeably lower than currently projected."

That makes sense. It is our contention that the natural rate of unemployment in most advanced countries is well below 4\% and perhaps even below 3\%. Employment rates and participation rates can rise and unemployment rates can fall and by a lot. ${ }^{8}$ Globalization has weakened worker's bargaining power. Migrant flows may have put downward pressure on wages and greased the wheels of the labor market as their presence increased mobility. The decline in the home ownership rate, which slows job creation and increases unemployment, has helped mobility and lowered the natural rate (Blanchflower and Oswald, 2013).

The Great Recession exposed underlying economic weaknesses and displayed to the populace the possibility of catastrophic declines in house prices and pension pots. The balance between capital and labor shifted once again towards capital. Workers are frightened in a way that they weren't pre-recession. They are afraid that firms will move production facilities abroad or out-source: in addition, a public sector pay freeze has helped moderate private sector pay increases. Workers are frightened and have less bargaining power than before. Hence the natural rate has fallen and that is why there has been no spurt in wage growth as the unemployment rate fell from $8 \%$ to $6 \%$ and from $6 \%$ to $4 \%$.

As William Beveridge noted in 1944, "full employment means that unemployment is reduced to short intervals of standing by, with the certainty that very soon will be wanted in one's old job again or will be wanted in a new job that is within one's powers... it means that the jobs are at fair wages, of such a kind, and so located that the unemployed men can reasonably be expected to take them: it means, by consequence, that the normal lag between losing one job and finding another will be short" (p.18). We are a long way from that. We are standing by.

Staiger, Stock and Watson (1997a) examined the precision of estimates of the natural rate of unemployment. They note that the NAIRU 'is commonly taken to be the rate of unemployment at which inflation remains constant. Unfortunately, the NAIRU is not directly observable.... The task of measuring the NAIRU is further complicated by the general recognition that, plausibly, the NAIRU has changed over the post-war period, perhaps as a consequence of changes in labor markets." They further note that "a wide range of values of the NAIRU are consistent with the empirical evidence" and crucially, that the trigger point - when wages and prices start to rise - is poorly estimated. For example, they estimate a NAIRU for the US of $6.2 \%$ in 1990 with a 95\% confidence interval of $5.1 \%$ to $7.7 \%$. In Staiger, Stock and Watson (1997b) they argue that the tightest of the 95 percent confidence intervals for 1994 in the US is $4.8 \%$ to $6.6 \%$. They conclude that "it is difficult to estimate the level of unemployment at which the curve predicts is constant rate inflation."

It is our contention that the NAIRU has fallen sharply in the UK post the Great Recession and is likely closer to $3 \%$ - and maybe well below it - than to $4 \%$ or so as claimed by the MPC and others.

\footnotetext{
${ }^{8}$ There is an additional possibility that participation rates rise and those who were previously OLF move to
} unemployment and start looking for jobs which could imply the unemployment rate might rise rather than fall. 
In a recent speech MPC member Gertjan Vlieghe argues that a credible Phillips curve still exists in the UK. We disagree. His main evidence was, firstly, a plot of wage changes against the unemployment rate using AWE data published by the Office of National Statistics monthly for the period 2001-2017. He focused on regular pay, excluding bonuses, which makes little sense given that workers don't care what their pay is called. No other wage series in the world separates bonuses from total pay. Vlieghe showed that the data showed a negative relationship between unemployment and wage growth in the UK since 2001.

Chart 5 plots the monthly wage growth series and the monthly unemployment rates.

Another way to present the relationships is to estimate a best fit line. For the whole period the lines are

Wage change $=7.1590-.7054 *$ Unemployment rate

Wage change $=5.9133-.4751 *$ Underemployment rate

In Chart 5 using monthly data the fit is similar to equation (1a)

Wage change $=7.2611-.7385 *$ Unemployment rate

The best fit lines to the data period 2009 Q1 through 2017 Q4 gives a much smaller wage response for an equivalent unemployment rate.

Wage change $=3.8114-.2862 *$ Unemployment rate

Wage change $=3.6424-.2259 *$ Underemployment rate

It seems that the Phillips curve has flattened. This is equally true when one uses the underemployment rate as the measure of labour market slack rather than the unemployment rate. Further, the sharp changes in the coefficients between the two periods suggest instability in the relationship over the period. Thus, a hypothesis of no structural break in the relationship between underemployment or unemployment and wage inflation is rejected for each year from 2006 onward using standard Wald tests. In addition, the Elliott-Muller test for the absence of persistent time variation in the underemployment coefficient is decisively rejected (test statistic $=-45.232,1 \%$ critical value $=-11.05$ ) with a similar result being obtained for unemployment .

A simpler approach is to separate the unemployment, underemployment and wage inflation data into pre-recession, immediate post-recession and recent time periods. We do this in Chart 6 and Chart 7 where we plot Phillips curves using AWE average single month total pay data by quarter for the pre-recession (2001 Q2 to 2008 Q1), immediate post-recession (2009 Q3 to 2013 Q4) and later period (2014 Q1 -2017 Q4). For simplicity we omit the five recession quarters of 2008 Q22009 Q2. Chart 6 provides scatter plots for these three distinct time periods using the unemployment rate and Chart 7 does the same with the underemployment rate. In both, the unemployment and underemployment rates in the first period have best fit lines that slope upwards. The second period is essentially flat using the underemployment rate and slopes upwards again 
with the unemployment rate. Finally, there is a downward sloping Phillips curve with a very different and much flatter slope than we saw in equations $1 \mathrm{a}, 1 \mathrm{~b}$ and 2.

Wage change $=3.1927-.1898 *$ Unemployment rate

Wage change $=3.0812-.1340 *$ Underemployment rate

If we use equation $1 \mathrm{a}$ or $1 \mathrm{~b}$, versus 5 to see what wage growth the equation predicts at $3 \%$ unemployment the answers are $5.0 \%$ and $2.6 \%$, respectively. If we use equation 3 , the answer is $3.0 \%$. The Phillips curve has flattened, suggesting that the UK is still a long way from fullemployment.

The second piece of evidence in Vlieghe's speech was an econometric analysis estimating a wage growth - Phillips curve - equation using 256 observations at the industry level from 1997 through 2017. That is 21 years by 12 industries. He includes a lagged unemployment rate and a lagged dependent variable and a set of sector dummies, but does not include a full set of year effects, which is what would be required to find credible results. In any case his finding suggests an implausibly large impact of unemployment on pay - he finds that a "one percentage point increase in the unemployment rate in a sector lowers wage growth in that sector by half a percent in the following year." So, given that the unemployment rate has fallen from $8.5 \%$ to $4.3 \%$ then wage growth should have risen by approximately two percentage points. It has not, of course.

The UK unemployment rate hit $8.5 \%$ in September-November 2011, when the AWE total pay annual $3 \mathrm{mth} / 3 \mathrm{mth}$ growth rate was $1.9 \%$. In October-December 2017 the unemployment rate was 4.3\% while December 2017 wage growth was $2.5 \%$, so that goes in the wrong direction. Note that the earnings of full-time workers from the quarterly LFS averaged $4.0 \%$ in the years from 1998 through Jan-Mar 2008 and 1.9\% subsequently. ${ }^{9}$ Wage growth in the four quarters of 2011 averaged $1 \%$ versus $1.9 \%$ in the four quarters of 2017.

The concern is that aggregating wages and unemployment by industry sector may be a particular problem in the most recent years. First, new entrants to the labour market, such as the young, don't have an industry. Secondly, temporary workers, of which there are around 1.5 million, will likely switch industries frequently. Third, workers shift between industries more than they do between regions. A computer specialist works for three months for a retail store; then for three at a bank; then for three in a university and then three at an electronics company. A worker's present industry may not be their next or last. The gig economy has meant people move industries more than they did in the past. Fourth, the longer the spell of unemployment the less likely it is that the unemployed individual will return to their prior industry. Industry seems the wrong level of aggregation in a post Great Recession world.

We explored this issue further using the same LFS micro-data for the years 2001-2017. We constructed unemployment, underemployment and wages by twenty regions across 67 quarterly waves, using earnings weights, and then constructed equivalent annual wage change measure from

\footnotetext{
${ }^{9}$ Available as spreadsheet earn05.xls from the ONS.
} 
the LFS across four waves and then a four-wave lag. In total there are 1180 observations. ${ }^{10}$ Using a broadly equivalent specification to Vlieghe's, we were unable to find any significant unemployment or underemployment effects on wage growth. Vlieghe's analysis cannot rule out the possibility of a structural break in the series. In private communications Jan admitted as much.

"The point of the analysis was not about whether sectoral or regional data is preferred. We tried both, we were agnostic ex ante. As explained (in footnote 20), the results for regional data showed that inclusion of year dummies rendered the regional unemployment rate insignificant. After inspection of the data, we concluded that this is because, aside from permanent level differences, there is not enough cross-sectional variation across regions, everything moves too closely with the aggregate. There is more cross-sectional variation across sectors, so sectoral unemployment effects on wages are better identified. Whether there is more or less substitutability across regions or sectors is an empirical issue. Our results suggest there is sufficiently low substitutability across sectors to identify a significant effect of sectoral unemployment on sectoral wages, and the effect does not appear to be weakening over time.

Our results are consistent with a downshift in the Phillips Curve (less wage pressure for given unemployment rate). The downshift could be due a number of factors as we explain in the speech, and one of those factors is indeed a reduction in the NAIRU, which we discuss explicitly."

We conclude the relationship between wage growth and unemployment is much flatter in the recent period than in previous periods; a change in the unemployment rate has about half the response in wage growth compared to the prior period. That is not to say that wage growth will not rise toward $4 \%$ but not until there is much less slack in the labour market.

Chart 8 plots productivity growth rates per worker and employment growth rates for the UK from 2001. ${ }^{11}$ Employment growth picked up as productivity slowed. Employment growth rates, according to the ONS were as follows - where we calculate the average monthly annual growth rates of employment.

$\begin{array}{lr}1970 \mathrm{~s} & 0.4 \% \\ 1980 \mathrm{~s} & 0.6 \% \\ 1990 \mathrm{~s} & 0.2 \% \\ 2000-2007 & 1.0 \% \\ 2008-2010 & -0.1 \% \\ 2011-2017 & 1.3 \%\end{array}$

The Great Recession saw a fall in employment from 2008 through 2010. Then after that employment rose at an average record annual pace of $1.3 \%$. Over the period January 2010 through January 2018 , the employment rate rose from $58.0 \%$ to $60.9 \%$, while real average weekly wages

\footnotetext{
${ }^{10} \mathrm{As}$ an example, we regressed hourly wage changes on a 1-year lag (coeff=-.472, $\mathrm{t}=18.8$ ) and the unemployment rate (coeff $=-.0112, \mathrm{t}=0.37$ ) with $\mathrm{n}=1180$, adjusted $\mathrm{R}^{2}=.2505$. The results are similar with the underemployment rate and with weekly wages.

${ }^{11}$ The employment annual growth rates were simply taken from the ONS labour market release a01mar2018.xls, Table 1. We used the data for Jan-Mar for Q1; Apr-Jun for Q2; Jul-Sep for Q3 and Oct-Dec for Q4. Output per worker was obtained from the ONS series Output per workers: Whole Economy SA: Index 2015=100, UK. https://www.ons.gov.uk/employmentandlabourmarket/peopleinwork/labourproductivity/timeseries/a4ym/prdy
} 
fell from a high of $£ 522$ in February 2008 to $£ 488$ in January 2018, or by over $6 \%$. In contrast, in the USA employment rates fell from $62.9 \%$ to $60.4 \%$ while real weekly wages in the private sector rose from $\$ 343.72$ to $\$ 369.72$ (in 1982-1984 dollars).

As background we should also note that productivity growth has declined steadily over time in the UK. According to the ONS productivity rates were as follows

$\begin{array}{ll}1960 \mathrm{~s} & 2.88 \% \\ 1970 \mathrm{~s} & 2.48 \% \\ 1980 \mathrm{~s} & 2.07 \% \\ 1990 \mathrm{~s} & 2.04 \% \\ 2000 \mathrm{~s} & 1.01 \% \\ 2010-2017 & 0.73 \%\end{array}$

To put this in context, UK productivity is $17 \%$ below the average for the rest of the G7 in $2015 .^{12}$ By 2015, the UK produces in five days what it takes the US, Germany and France to produce in four. There is little or no sign of catch-up. It is hardly surprising that wages have not risen something structural has happened. Productivity growth is a third of what it was from 1960-2000.

Higher productivity tends to lead to higher real wages and is associated with higher consumption levels and better health. ${ }^{13}$ It seems that another contributory factor to slowing wage growth has been the falling rate of productivity increase. The very low wage growth rates in the last few periods have occurred when output per head was growing at less than $1 \%$ and employment growth was slowing. ${ }^{14}$ Low paid workers were hired. There was an industry-wide slowdown in business investment during the crisis and subdued growth since, which helps to explain the productivity slowdown.

Consistent with that is the recent work by Haltiwanger et al (2018), in the United States who found strong evidence of a firm wage ladder that was highly pro-cyclical. During the Great Recession, this firm wage ladder collapsed, with net worker reallocation to higher wage firms falling to zero. They found that in the Great Recession, movement out of the bottom rung of the wage ladder declined by 85 percent, with an associated 40 percent decline in earnings growth. They find that upward progress from the bottom rung of the job ladder declines by 40 percent in contractions, relative to expansions.

Productivity is low when wage growth is low. A pay freeze in the public sector that has existed in the UK since 2010 has not helped to motivate staff. Workers on low pay are not motivated to work

12 'International comparisons of UK productivity (ICP), final estimates, 2015', Statistical Bulletin, ONS, $5^{\text {th }}$ April 2017.

${ }^{13}$ Silvana Tenreyro 'The fall in productivity growth: causes and implications', Peston Lecture, Queen Mary University of London 15 January 2018.

${ }^{14}$ Rates were 2015Q3 0.4\% 2015Q4 -0.1\%; 2016Q1 $0.3 \%$; 2016Q2 -0.5\%; 2016Q3 0.4\%; 2016Q4 0.9\%; 2017Q1

0.8\%; 2017Q2 0.8\%; 2017Q3 0.9\%. 
harder. In addition, in contrast to the United States, the employment rate in the UK has recovered to post-recession levels. ${ }^{15}$ In both countries private sector unionization rates have collapsed so workers appear to have less bargaining power than in the past. ${ }^{16}$

Blundell et al (2014) have noted that the supply of workers in this recession was higher than in previous recessions: the labour supply curve has shifted to the right. However, despite the increase in supply occurring among groups towards the lower end of the jobs market, they found there is strong evidence against the composition or quality of labour hypothesis as a potential explanation for the reduction in wages and hence productivity that we observe. They found that there are more individuals willing to work at any given wage and thus that there is likely to be greater competition for jobs. As a consequence, Blundell et al argue, workers are likely to have lower reservation wages than in the past and seem to attach more weight to staying in work (because their expected time to find another job is longer than in the past) than on securing higher wages and are thus willing to accept lower wages in exchange for holding onto their job.

Stansbury and Summers (2018), for the US, find evidence of linkage between productivity and compensation: over 1973-2016, one percentage point higher productivity growth has been associated with 0.7 to 1 percentage points higher median and average compensation growth and with 0.4 to 0.7 percentage points higher production/nonsupervisory compensation growth. They further find the relationship between average compensation and productivity in Canada; West Germany (pre-unification), the UK and the USA to be strong and positive with the effects somewhat weaker for France, Italy and Japan.

UK forecasters, including the Bank of England, have consistently predicted that productivity growth would recover to a rate close to its 1970s-2000s average. The Office for Budget Responsibility (OBR) continued to assume this recovery would occur, although reasons were never given. Chart 9 is taken from the OBR's March 2017 Forecast Evaluation Report and shows successive and essentially unchanging and terrible OBR productivity forecasts and the actual data. The black line on the chart shows the outcome over the period from 2009 through 2017 along with sixteen successive forecasts. Each forecast implausibly slopes up sharply and are basically parallel to each other. Each of them forecasts an explosion of productivity growth which never happened but there was zero learning and no change. The latest March 2017 report showed a very slight shallowing. Each assumed the productivity puzzle was solved when it wasn't. There was no learning.

Of interest is the timing of the collapse of productivity growth. This follows almost exactly from the introduction of austerity in the UK's Budget of June 2010. The changes took a little time to have an impact so if we assume 2011 Q2 as a reasonable starting point for the effects of austerity output per hour was 103.7, with 2009=100. By 2017 Q2 it was 103.9. Austerity killed productivity.

\footnotetext{
15 The $16+$ employment rate in the US in January 2008 was $62.9 \%$ versus $60.4 \%$ in January 2018 . In contrast in the UK they were $60.4 \%$ and $60.9 \%$ respectively on these dates - source BLS and ONS.

${ }^{16}$ According to www.unionstats.gsu.edu private sector unionization rates in the US in 2017 were $6.5 \%$ down from $10.3 \%$ since 1995 versus, according to the ONS, were $13.4 \%$ in the UK down from $21.4 \%$ in 1995. https://www.gov.uk/government/uploads/system/uploads/attachment_data/file/616966/trade-union-membershipstatistical-bulletin-2016-rev.pdf
} 
In October 2017, in its Forecast Evaluation Report (FER) the OBR produced a mea culpa admitting it had been wrong all along; the productivity puzzle had not been solved and the UK economy was not set to mean revert to pre-recession levels.

"One recurring theme in past FERs has been productivity falling short of our forecasts.... Our rationale for basing successive forecasts on an assumed pick-up in prospective productivity growth has been that the post-crisis period of weakness was likely to reflect a combination of temporary, albeit persistent, influences. And as those factors waned, so it seemed likely that productivity growth would return towards its long-run historical average." (p.6)

And later

"While we continue to believe that there will be some recovery from the very weak productivity performance of recent years, the continued disappointing outturns, together with the likelihood that heightened uncertainty will continue to weigh on investment, means that we anticipate significantly reducing our assumption for potential productivity growth over the next five years in our forthcoming November 2017 forecast," (p.7).

Flat productivity led to flat wage growth.

\section{Conclusion}

The UK Phillips curve appears to have flattened sharply - the constant and the slope have both halved.

Wage growth continues to be benign despite low unemployment rates in the UK and the US in particular. It seems that the unemployment rate understates labour market slack. But perhaps more importantly, something has changed in the years since the Great Recession. The very low level of the unemployment of $4.3 \%$ prevailing in the UK at the time of writing may not indicate that the UK is close to full-employment.

Our findings suggest that some of the reason for that is because the unemployment rate understates labour market slack. Underemployment is more important than unemployment in explaining the weakness of wage growth in the UK. In the pre-recession years the underemployment rate hit a low of $3.8 \%$ in 2004 Q1 and was associated with steadily rising wage growth which hit $4.5 \%$ in 2005 Q3 (Appendix 1). There is every reason to believe that now it could go even lower - perhaps even below $3 \%$ - before there is an equivalent up-tick in wage growth.

There is every reason to believe that the natural rate of unemployment has fallen sharply since the Great Recession. That is why there hasn't been a burst of wage growth as the unemployment rate has fallen, from $8 \%$ to $6 \%$ to close to $4 \%$. In our view the NAIRU in the UK may well be nearer to $3 \%$, and even below it, than around $5 \%$ which other commentators including the MPC and the OBR believe.

In the years 2000-2008 there was no relationship between high wage growth, of around 4\% and the relatively low unemployment rate. Then the Great Recession came along, and everything 
shifted down with lower wage growth and higher unemployment. Once recovery happened there was a transition to a new flatter equilibrium with low unemployment of less than $5 \%$ and low wage growth of around $2 \%$.

A big question is how low can unemployment go. William Beveridge (1960) tells the story in the prologue to his book, written sixteen years later, that as a 'conservative rather than unduly hopeful aim' of the amount of temporary idleness that might be expected under full employment he had suggested in 1944 a figure of 3\% of the labor force at any time. When Keynes saw this number, he wrote to Beveridge to say that he saw no harm in aiming at 3 percent but that he would be surprised if it could go so low in practice. During the twelve years from 1948 through 1959 Beveridge was surprised to find the unemployment rate averaged $1.5 \%$ with no wage explosion. Here are the UK numbers: $1948-1950=1.5 \% ; 1951=1.2 \% ; 1952=2.0 \% ; 1953=1.6 \% ; 1954=1.3 \%$; $1955=1.1 \% ; 1956=1.2 \% ; 1957=1.4 \% ; 1958=2.1 \%$ and $1959=2.2 \%$. Unemployment may surprise on the downside again.

Underemployment continues to push down on wage pressure even though the unemployment rate is low. Over and above that we present evidence that the UK Phillips curve has flattened and as a result the UK NAIRU has shifted down. The combination of elevated underemployment and a flattened Phillips curve means that wage growth is not going to take off any time soon. 


\section{References.}

Bell, D.N.F. and D.G. Blanchflower (2018), 'Underemployment and the lack of wage pressure in the UK', National Institute Economic Review, \# 243, February, pp. R53-R61.

Bell, D.N.F. and D.G. Blanchflower (2014), 'Labour market slack in the UK', National Institute Economic Review \#229 August, F4-F11.

Bell, D.N.F. and D.G. Blanchflower (2013), 'Underemployment in the UK revisited', National Institute Economic Review, \#224, May pp. F8-F22.

Bell, D.N.F. and D.G. Blanchflower (2011), 'Youth underemployment in the UK in the Great Recession', National Institute Economic Review, January, pp. R1-R11.

Beveridge, W.H. (1960), Full Employment in a Free Society. A Report, Routledge, NY first published in 1944.

Blanchflower, D.G. (2015), 'As good as it gets? The UK Labour Market in recession and recovery', National Institute Economic Review \# 231, February, pp. F76-F80.

Blanchflower, D.G. and A.T. Levin (2015) 'Labor market slack and monetary policy', NBER working paper \#21094.

Blanchflower, D.G. and A.J. Bryson (2010), 'The wage impact of trade unions in the UK public and private sectors,' Economica, Vol. 77 Issue: 305, pp. 92-109, January.

Blanchflower, D.G. and A.J. Oswald (2013), 'Does high home-ownership impair the labor market?' NBER Working Paper \#19079, May.

Blanchflower, D.G. and A.J. Oswald (1994a), The wage curve, MIT Press, Cambridge, MA.

Blanchflower, D.G. and A.J. Oswald (1994b), 'Estimating a British wage curve, 1973-1990,' Economic Journal, September, pp.1025-1043.

Blanchflower, D.G. and C. Shadforth (2009), 'Fear, unemployment and migration,' The Economic Journal, 119(535), February, pp. F136-F182.

Blundell, R., C. Crawford and W. Jin (2014), 'What can wages and employment tell us about the UK"s productivity puzzle?', The Economic Journal, 124, May, pp. 307-407.

Elliott, G., and U.K. Müller (2006), 'Efficient tests for general persistent time variation in regression coefficients', The Review of Economic Studies, 73(4), pp. 907-940.

Friedman, M. (1968), 'The role of monetary policy', The American Economic Review, LVIII, vol. 1, March, pp. 1-17. 
Haltiwanger, J.C., H.R. Hyatt, L.B. Kahn and E. McEntarfer (2018), 'Cyclical job ladders by firm size and firm wage', American Economic Journal: Macroeconomics, 10(2), pp. 52-85

Hirsch, B., E.J. Jahn, and C. Schnabel (2017). 'Do employers have more monopsony power in slack labor markets?' Industrial and Labor Relations Review, July.

Hong, G.H., Z. Kóczán, W. Lian, and M. Nabar (2018), 'More slack than meets the eye? Recent wage dynamics in advanced economies,' IMF Working Paper /18/50, IMF Research Department

Staiger, D., J. Stock and M. Watson (1997a), 'How precise are estimates of the natural rate of unemployment?', Reducing inflation: Motivation and Strategy, edited by C.D. Romer and D.H. Romer, University of Chicago Press.

Staiger, D., J. Stock and M. Watson (1997b), 'The NAIRU, unemployment and monetary policy', Journal of Economic Perspectives, 11(1), Winter, pp. 33-49.

Stansbury, A.M. and L.H. Summers (2018), 'Productivity and pay: is the link broken?', NBER Working Paper 24165

Weale, M. (2014), 'Slack and the labour market', speech given at the Thames Valley Chamber of Commerce, $20^{\text {th }}$ March.

http://www.bankofengland.co.uk/publications/Documents/speeches/2014/speech716.pdf 
Table 1. Annual real wage growth $\%$ in 2016 constant prices and involuntary part-time as a $\%$ total employment, 2007, 2012 and 2016.

\begin{tabular}{lrr|rrr} 
& \multicolumn{2}{c|}{ Real wage growth } & \multicolumn{3}{c}{ Involuntary part-time rate } \\
Australia & $2000-2008$ & $2008-2016$ & 2007 & 2012 & 2016 \\
Austria & 12 & 5 & 6.7 & 7.6 & 8.9 \\
Belgium & 8 & 1 & 2.7 & 2.5 & 3.6 \\
Canada & 2 & 2 & 3.6 & 2.6 & 2.3 \\
Denmark & 14 & 9 & 4.0 & 5.1 & 4.8 \\
Finland & 14 & 9 & 3.1 & 4.3 & 3.7 \\
France & 14 & 3 & 2.9 & 3.2 & 0.9 \\
Germany & 9 & 10 & 5.3 & 5.3 & 7.8 \\
Greece & 2 & 10 & 5.3 & 3.9 & 3.1 \\
Ireland & 18 & -18 & 2.4 & 4.8 & 6.9 \\
Italy & 21 & 8 & 2.0 & 0.2 & 7.2 \\
Japan & 4 & -1 & 5.4 & 9.7 & 11.9 \\
Netherlands & -1 & 0 & 4.5 & 5.2 & 4.4 \\
New Zealand & 7 & 6 & 2.0 & 3.9 & 4.2 \\
Portugal & 20 & 8 & 3.9 & 4.9 & 5.4 \\
Spain & -2 & -3 & 3.4 & 5.4 & 4.7 \\
Sweden & 5 & 2 & 4.1 & 9.6 & 9.9 \\
Switzerland & 17 & 11 & 7.7 & 8.1 & 5.9 \\
United Kingdom & 8 & 5 & 1.8 & 2.5 & 2.9 \\
United States & 15 & 0 & 2.4 & 5.0 & 3.9 \\
Source: OECD & 8 & 7 & 0.8 & 1.8 & 1.3
\end{tabular}

Source: OECD and Hong et al (2018).

Table 2. Seventeen Successive MPC Wage Forecasts, for 2014-2020 (\%)

\begin{tabular}{|c|c|c|c|c|c|c|c|}
\hline & & 2015 & 2016 & 2017 & 2018 & 2019 & 2020 \\
\hline 2014 Q1 & $23 / 4$ & $33 / 4$ & $33 / 4$ & & & & \\
\hline 2014 Q2 & $21 / 2$ & $31 / 2$ & $33 / 4$ & & & & \\
\hline 2014 Q3 & $11 / 4$ & 3.3 & 4 & & & & \\
\hline 2014 Q4 & $11 / 4$ & 3.3 & $33 / 4$ & $33 / 4$ & & & \\
\hline 2015 Q1 & & $31 / 2$ & 4 & 4 & & & \\
\hline 2015 Q2 & & $2^{1 / 2}$ & 4 & 4 & & & \\
\hline 2015 Q3 & & 3 & $33 / 4$ & $41 / 2$ & & & \\
\hline 2015 Q4 & & $2^{1 / 2}$ & $33 / 4$ & 4 & $41 / 4$ & & \\
\hline 2016 Q1 & & & 3 & $33 / 4$ & $41 / 4$ & & \\
\hline 2016 Q2 & & & 3 & $33 / 4$ & 4 & & \\
\hline 2016 Q3 & & & $23 / 4$ & 3 & $31 / 2$ & & \\
\hline 2016 Q4 & & & $21 / 2$ & $23 / 4$ & $33 / 4$ & $33 / 4$ & \\
\hline 2017 Q1 & & & & 3 & $33 / 4$ & $31 / 4$ & \\
\hline 2017 Q2 & & & & 2 & $31 / 2$ & $33 / 4$ & \\
\hline 2017 Q3 & & & & 2 & 3 & $31 / 4$ & \\
\hline 2017 Q4 & & & & $21 / 4$ & 3 & $31 / 4$ & $31 / 4$ \\
\hline 2018 Q1 & & & & $21 / 2$ & 3 & $31 / 4$ & $31 / 2$ \\
\hline Outcome & 1.1 & 2.6 & 2.4 & 1.9 & & & \\
\hline
\end{tabular}


Table 3. Distribution of under and over hours

$\begin{array}{lccc} & & 2001-2008 & \\ & \text { Under hours } & \text { Over hours } & \text { \% of total hours worked } \\ \text { Part-time: student } & 2.8 & 0.2 & 4.0 \\ \text { Part-time: ill or disabled } & 2.7 & 0.5 & 0.6 \\ \text { Part-time: could not find full-time job } & 10.0 & 0.1 & 2.2 \\ \text { Part-time: did not want full-time job } & 1.4 & 0.5 & 18.3 \\ \text { Part-time: no reason given } & 5.1 & 0.4 & 0.1 \\ \text { Full-time } & 0.4 & 1.3 & 74.8 \\ \text { Percent accounted for by PTWFT } & 23 \% & & \end{array}$

2009-2017

Part-time: student $\quad 3.6$

Under hours

Over hours \% of total hours worked

Part-time: ill or disabled $\quad 3.2$

Part-time: could not find full-time job $\quad 11.0$

Part-time: did not want full-time job $\quad 1.7$

Part-time: no reason given $\quad 5.4$

Full-time $\quad 0.6$

Percent accounted for by PTWFT $\quad 31 \%$

$\begin{array}{rr}0.1 & 3.6 \\ 0.5 & 0.7 \\ 0.1 & 4.1 \\ 0.5 & 18.1 \\ 0.3 & 0.2 \\ 1.3 & 73.3\end{array}$


Table 4. Hourly wage equations, 2001-2017

\begin{tabular}{|c|c|c|c|}
\hline & 2001-2017 & 2001-2008 & 2009-2017 \\
\hline Under hours & $-.0058(41.72)$ & $-.0048(23.91)$ & $-.0066(33.94)$ \\
\hline Over hours & $.0031(23.58)$ & $.0031(17.65)$ & $.0029(14.79)$ \\
\hline PT student & $-.1791(57.56)$ & $-.1792(44.70)$ & $-.1740(35.69)$ \\
\hline PT disabled & $-.2560(40.38)$ & $-.2488(28.42)$ & $-.2632(28.70)$ \\
\hline PTWFT & $-.1760(53.29)$ & $-.1714(33.63)$ & $-.1757(39.98)$ \\
\hline PT DWFT & $-.1239(87.87)$ & $-.1363(71.88)$ & $-.1094(52.09)$ \\
\hline PT no reason & $-.1141(7.50)$ & $-.1272(6.19)$ & $-.1081(4.80)$ \\
\hline Age & $.0538(201.70)$ & $.0566(158.52)$ & $.0528(131.12)$ \\
\hline Age squared & $-.0006(185.79)$ & $-.0006(148.08)$ & $-.0006(119.27)$ \\
\hline Male & $.1611(146.68)$ & $.1596(107.47)$ & .1623 (99.79) \\
\hline NVQ 4 & $-.2462(133.98)$ & $-.2437(95.97)$ & $-.2544(95.48)$ \\
\hline NVQ 3 & $-.3965(257.32)$ & $-.4055(187.66)$ & $-.3912(177.54)$ \\
\hline Apprenticeship & $-.5238(209.04)$ & $-.5443(170.06)$ & $-.4955(123.14)$ \\
\hline NVQ 2 & $-.5192(341.58)$ & $-.5292(260.61)$ & $-.5160(222.37)$ \\
\hline Other qualifications & $-.5979(343.55)$ & $-.6267(260.66)$ & $-.5713(225.79)$ \\
\hline No qualifications & $-.7210(339.35)$ & $-.7364(274.64)$ & $-.6930(196.68)$ \\
\hline Years tenure & .0185 (109.19) & $.0190(82.39)$ & $.0179(71.42)$ \\
\hline Tenure squared & $-.0002(44.94)$ & $-.0003(34.80)$ & $-.0002(29.07)$ \\
\hline Wave dummies & 66 & 30 & 35 \\
\hline Region dummies & 19 & 19 & 19 \\
\hline Constant & 1.07731 & 1.0541 & 1.3075 \\
\hline Adjusted $\mathrm{R}^{2}$ & .4250 & .4287 & .3768 \\
\hline $\mathrm{N}$ & 842,929 & 446,968 & 395,961 \\
\hline
\end{tabular}


Table 5. Time series log wage and wage growth equations in an unbalanced country panel, 1976-2016

$\begin{array}{lcccc}\text { Dependent variable } & \log \mathrm{W}_{\mathrm{t}} & \log \mathrm{W}_{\mathrm{t}} & \log _{\mathrm{t}} & \operatorname{LogW}_{\mathrm{t}}-\log _{\mathrm{t}-1} \\ \text { Log unemployment rate } \mathrm{t}-1 & -.0336(15.03) & -.0289(9.66) & -.0239(7.25) & -.0239(7.25) \\ \text { Log Wage } & .9931(1026.25) & .9558(368.52) & .9063(119.96) & -.0937(12.40) \\ \text { Log PTWFT\% } & -.0143(7.54) & -.0114(4.79) & -.0144(5.91) & -.0144(5.91) \\ & & & & \text { Yes } \\ \text { Country dummies } & \text { No } & \text { Yes } & \text { Yes } & \text { Yes } \\ \text { Year dummies } & \text { No } & \text { No } & \text { Yes } & .3312 \\ \text { Constant } & .1424 & .2598 & .3312 & .6333 \\ \text { Adjusted R } & .9994 & .9998 & .9998 & 686\end{array}$

Source: Hong et al (2018) and own calculations 


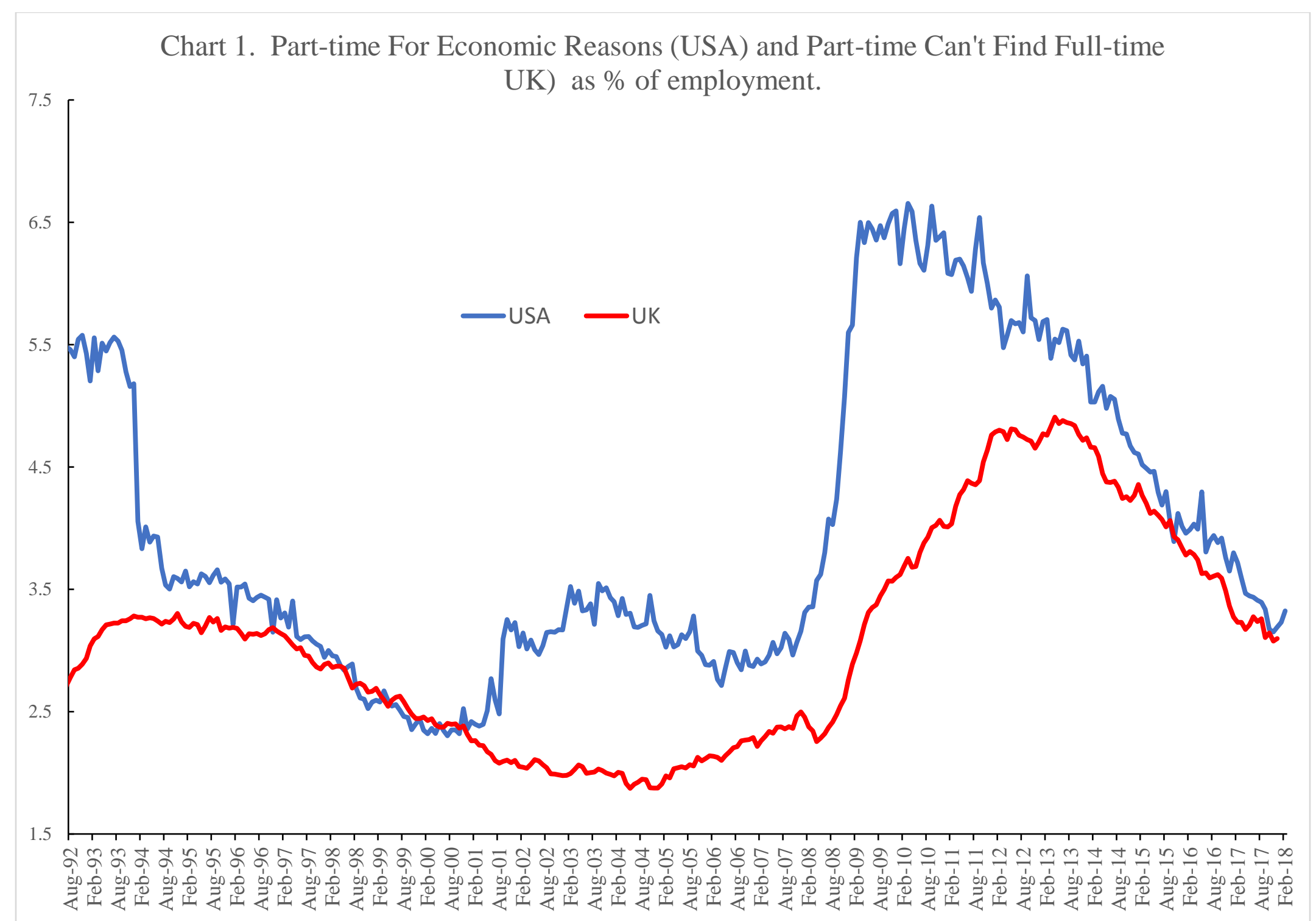




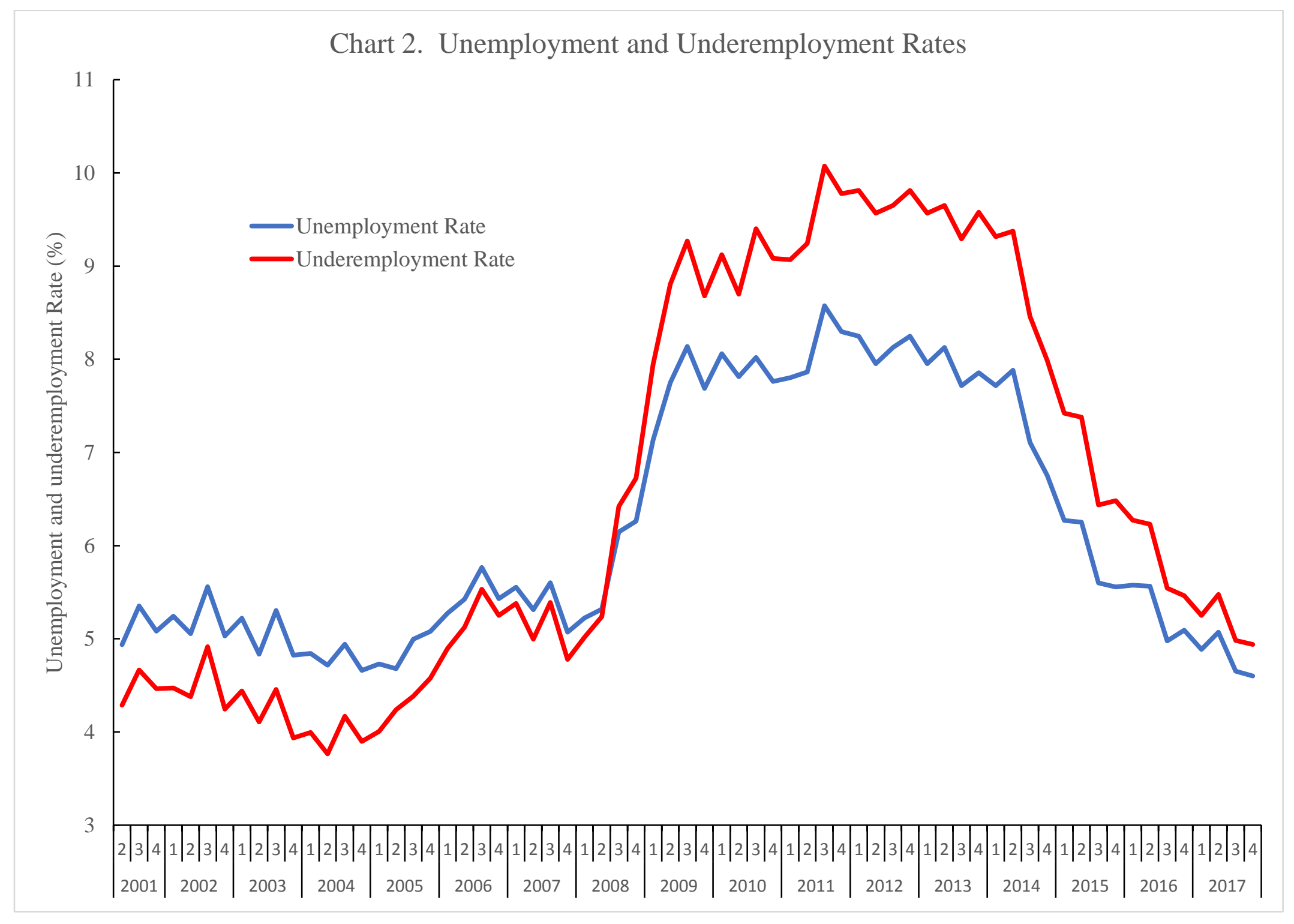




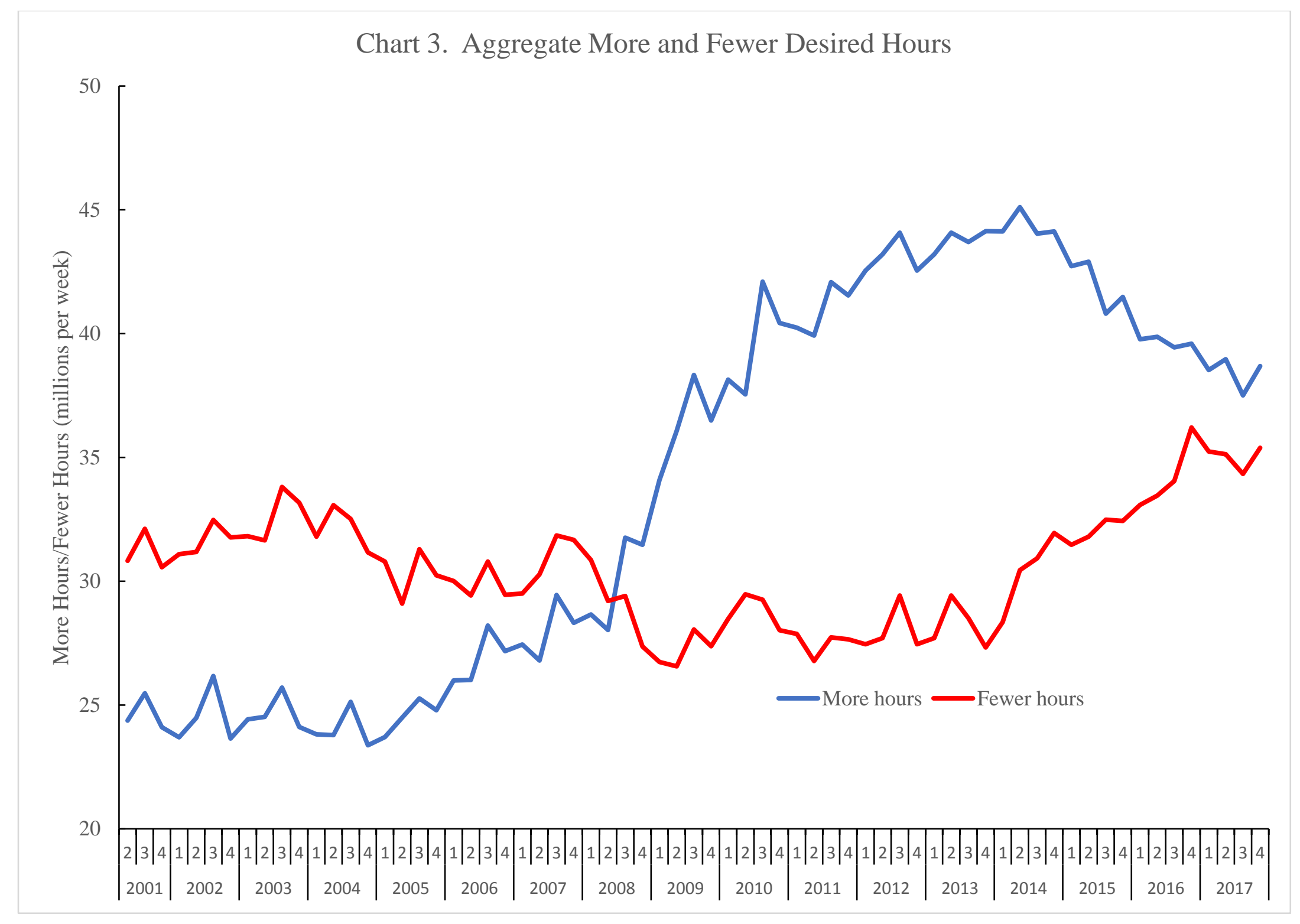




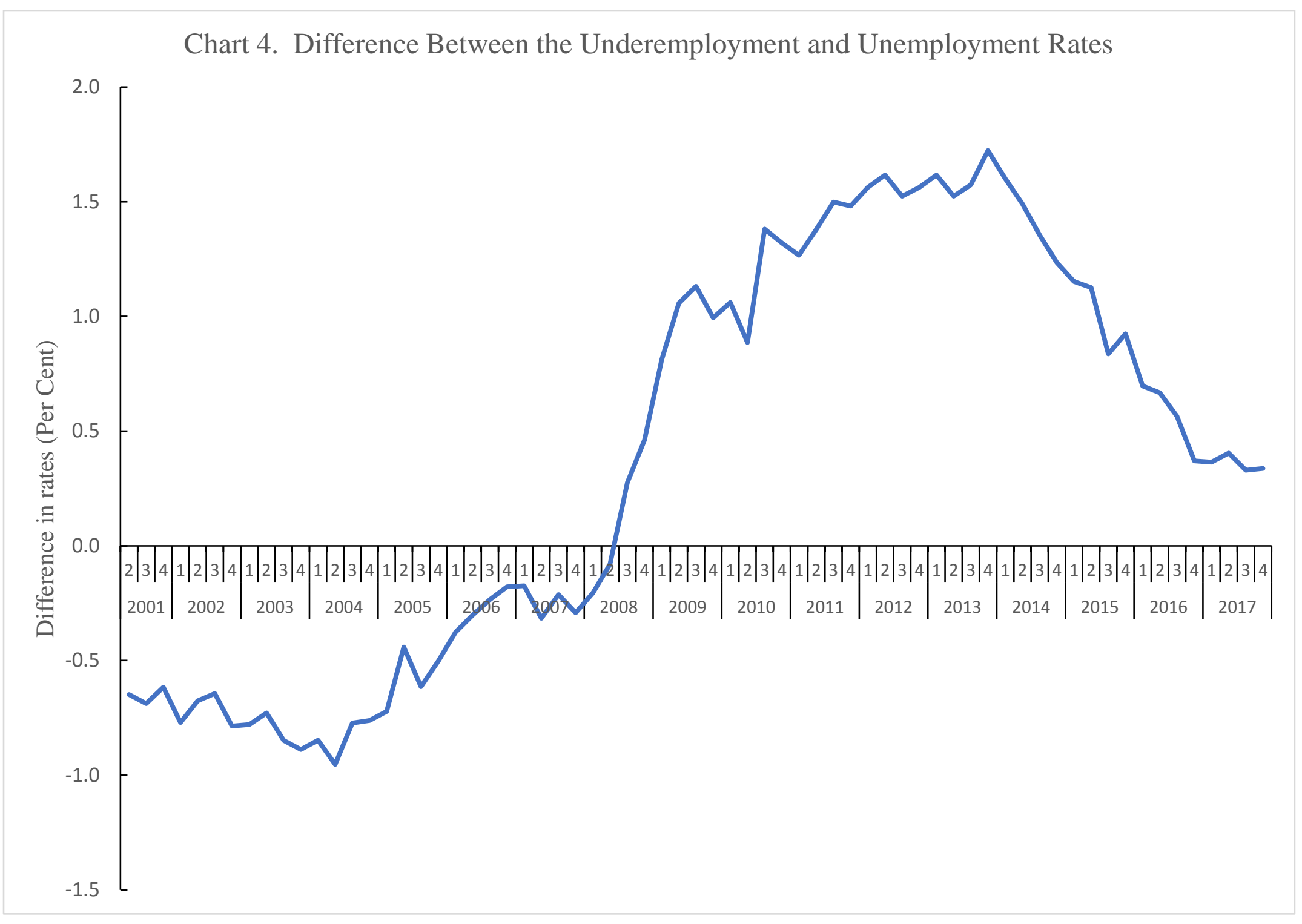




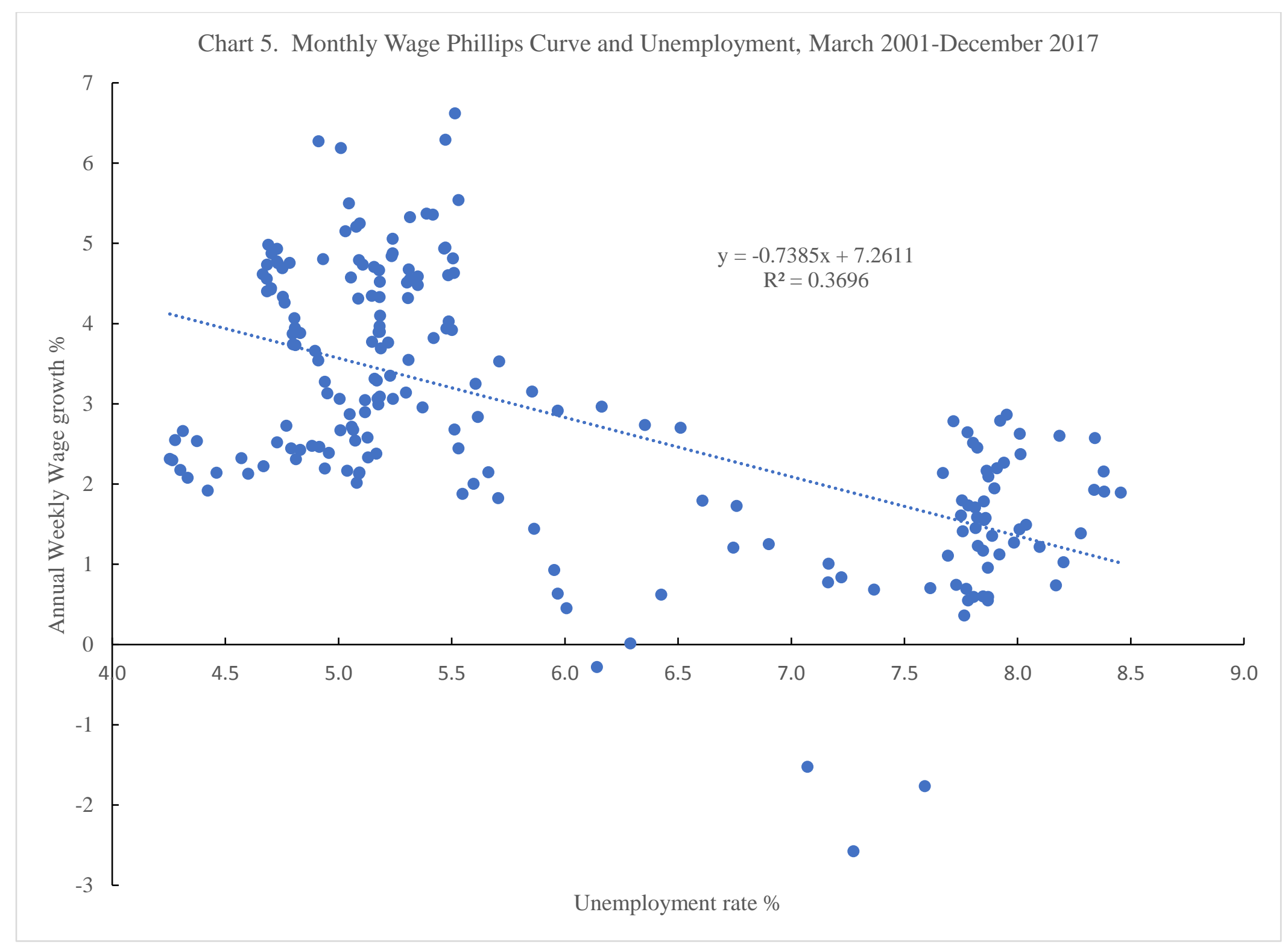



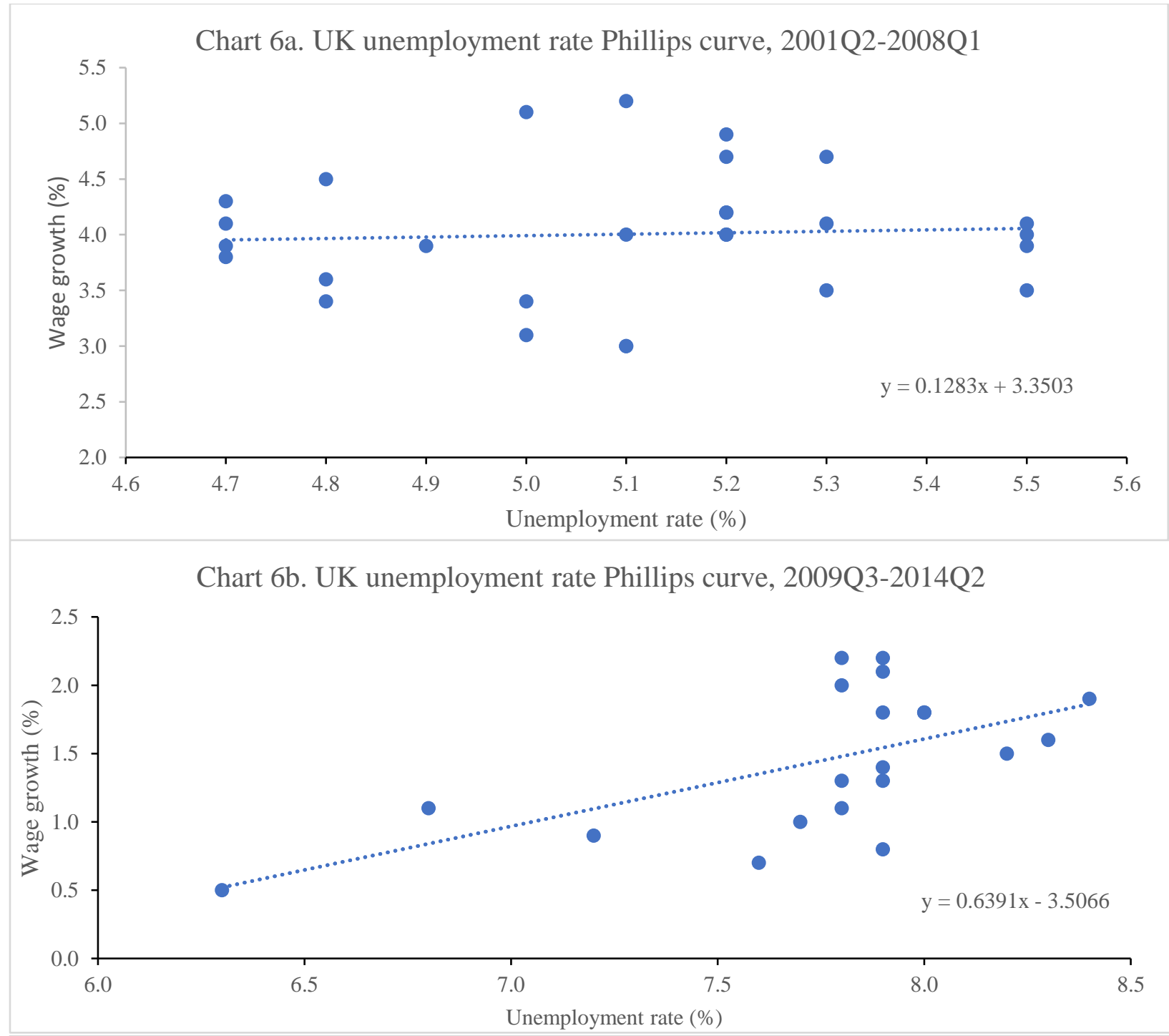

Chart 6c. UK unemployment rate Phillips curve, 2014Q3-2017Q4

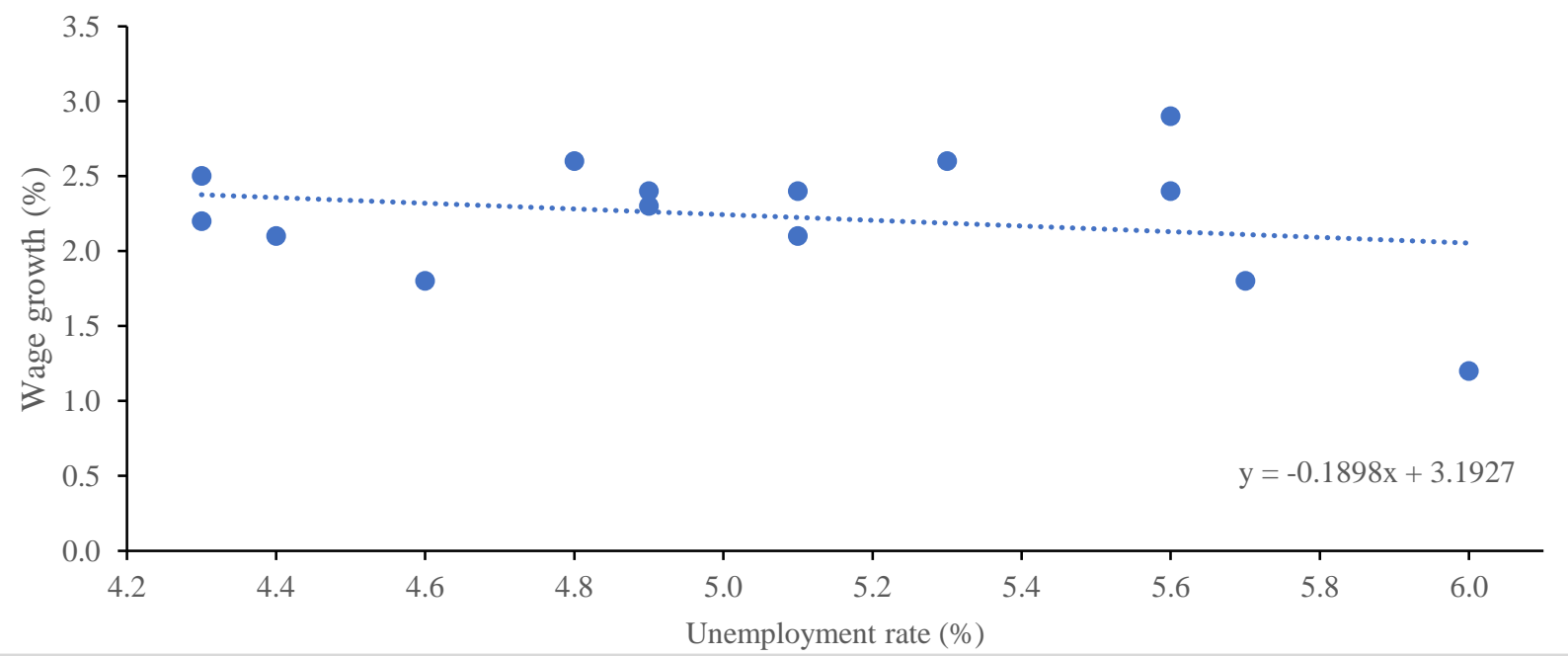



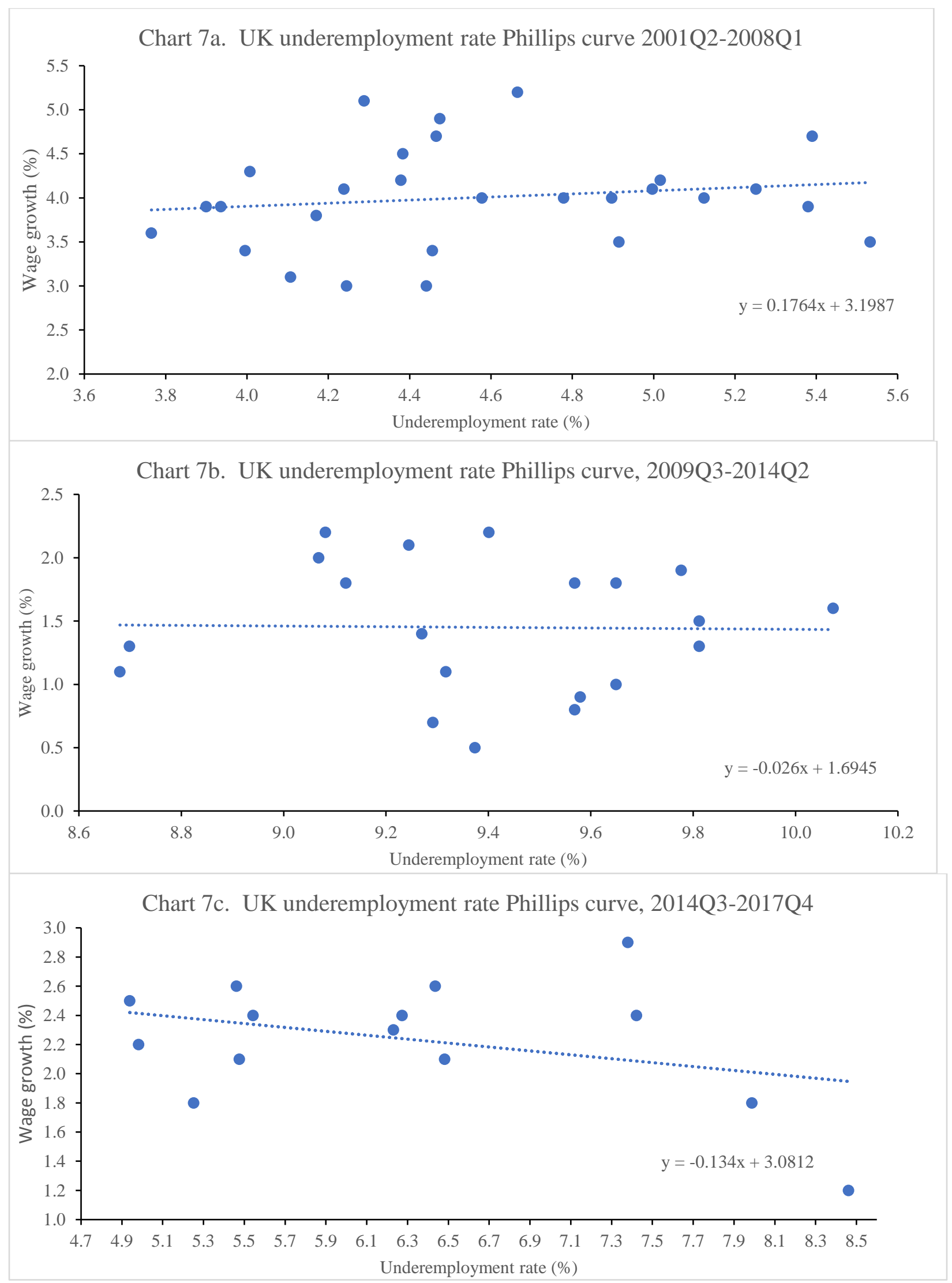


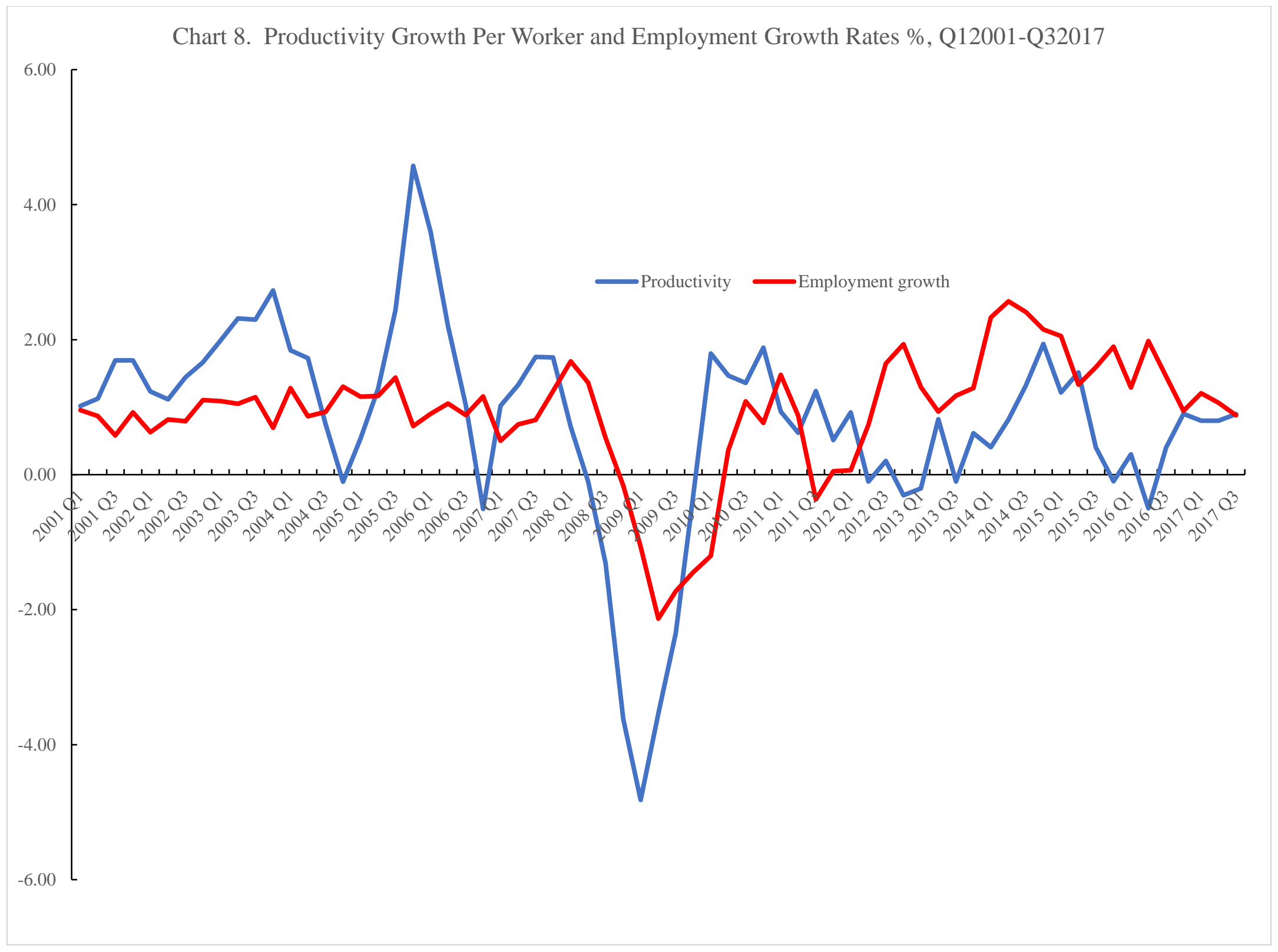

30 
Chart 9. Successive OBR Productivity Forecasts (output per hour) for the UK; 2010-2017

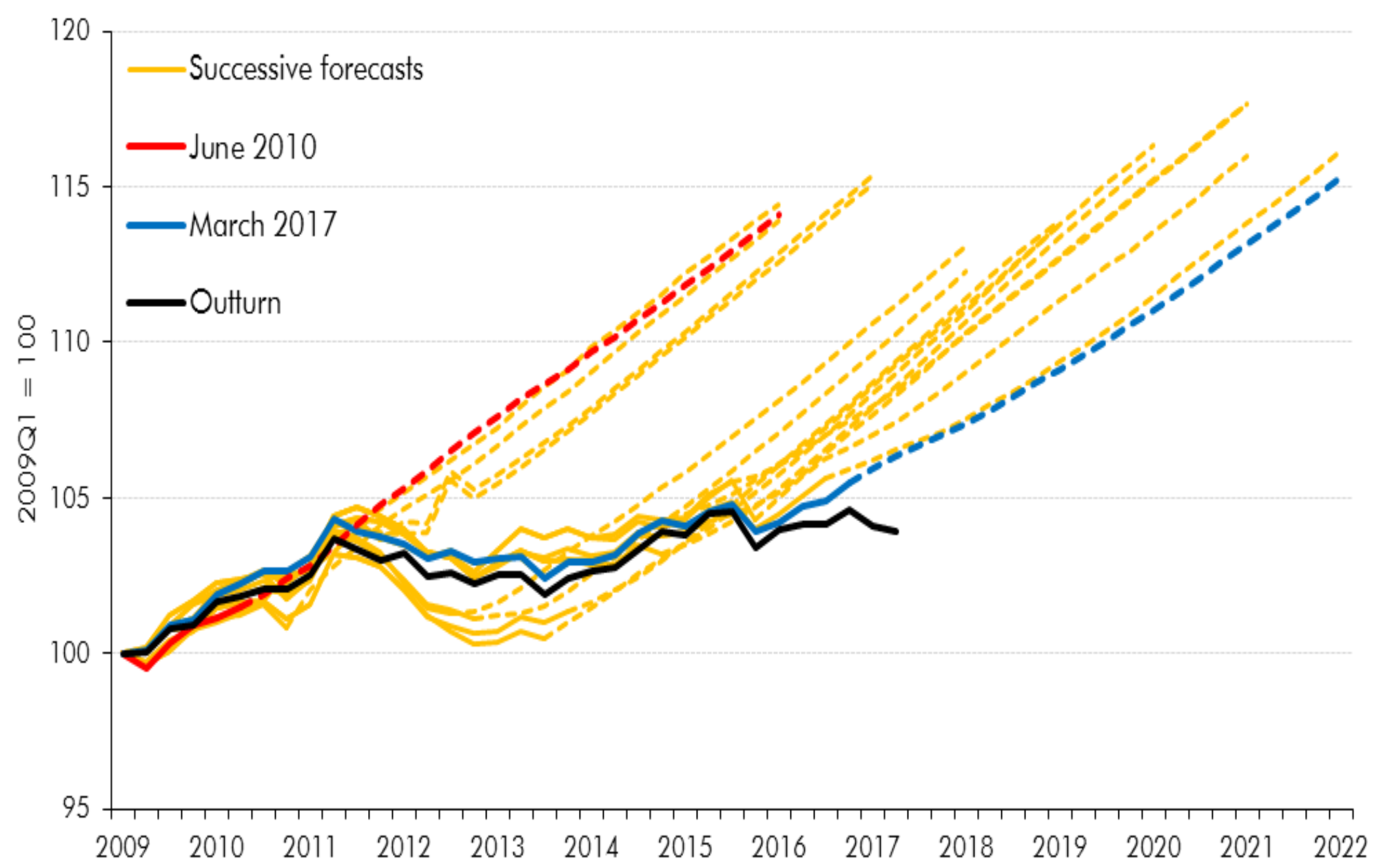

Note: Solid lines represent the outturn data that underpinned the forecasts at the time (the dashed lines). Source: ONS, OBR 
Appendix 1. UK Unemployment and Underemployment Rates, and Growth in Average Weekly Earnings

\begin{tabular}{|c|c|c|c|c|}
\hline Year & Quarter & $\begin{array}{c}\text { Unemployment } \\
\text { Rate }\end{array}$ & $\begin{array}{c}\text { Underemployment } \\
\text { Rate }\end{array}$ & $\begin{array}{l}\text { AWE total } \\
\text { pay growth rate }\end{array}$ \\
\hline \multirow[t]{3}{*}{2001} & Q2 & 5.0 & 4.3 & 5.1 \\
\hline & Q3 & 5.1 & 4.7 & 5.2 \\
\hline & Q4 & 5.2 & 4.5 & 4.7 \\
\hline \multirow[t]{4}{*}{2002} & Q1 & 5.2 & 4.5 & 4.9 \\
\hline & Q2 & 5.2 & 4.4 & 4.2 \\
\hline & Q3 & 5.3 & 4.9 & 3.5 \\
\hline & Q4 & 5.1 & 4.2 & 3.0 \\
\hline \multirow[t]{4}{*}{2003} & Q1 & 5.1 & 4.4 & 3.0 \\
\hline & Q2 & 5.0 & 4.1 & 3.1 \\
\hline & Q3 & 5.0 & 4.5 & 3.4 \\
\hline & Q4 & 4.9 & 3.9 & 3.9 \\
\hline \multirow[t]{4}{*}{2004} & Q1 & 4.8 & 4.0 & 3.4 \\
\hline & Q2 & 4.8 & 3.8 & 3.6 \\
\hline & Q3 & 4.7 & 4.2 & 3.8 \\
\hline & Q4 & 4.7 & 3.9 & 3.9 \\
\hline \multirow[t]{4}{*}{2005} & Q1 & 4.7 & 4.0 & 4.3 \\
\hline & Q2 & 4.7 & 4.2 & 4.1 \\
\hline & Q3 & 4.8 & 4.4 & 4.5 \\
\hline & Q4 & 5.1 & 4.6 & 4.0 \\
\hline \multirow[t]{4}{*}{2006} & Q1 & 5.2 & 4.9 & 4.0 \\
\hline & Q2 & 5.5 & 5.1 & 4.0 \\
\hline & Q3 & 5.5 & 5.5 & 3.5 \\
\hline & Q4 & 5.5 & 5.3 & 4.1 \\
\hline \multirow[t]{4}{*}{2007} & Q1 & 5.5 & 5.4 & 3.9 \\
\hline & $\mathrm{Q} 2$ & 5.3 & 5.0 & 4.1 \\
\hline & Q3 & 5.3 & 5.4 & 4.7 \\
\hline & Q4 & 5.2 & 4.8 & 4.0 \\
\hline \multirow[t]{4}{*}{2008} & Q1 & 5.2 & 5.0 & 4.2 \\
\hline & Q2 & 5.3 & 5.2 & 3.9 \\
\hline & Q3 & 5.8 & 6.4 & 3.3 \\
\hline & Q4 & 6.3 & 6.7 & 3.3 \\
\hline \multirow[t]{4}{*}{2009} & Q1 & 7.0 & 7.9 & 2.5 \\
\hline & Q2 & 7.7 & 8.8 & 2.1 \\
\hline & Q3 & 7.9 & 9.3 & 1.4 \\
\hline & Q4 & 7.8 & 8.7 & 1.1 \\
\hline \multirow[t]{4}{*}{2010} & Q1 & 8.0 & 9.1 & 1.8 \\
\hline & Q2 & 7.9 & 8.7 & 1.3 \\
\hline & Q3 & 7.8 & 9.4 & 2.2 \\
\hline & Q4 & 7.9 & 9.1 & 2.2 \\
\hline \multirow[t]{2}{*}{2011} & $\mathrm{Q} 1$ & 7.8 & 9.1 & 2.0 \\
\hline & Q2 & 7.9 & 9.2 & 2.1 \\
\hline
\end{tabular}




$\begin{array}{lrrrr} & \text { Q3 } & 8.3 & 10.1 & 1.6 \\ 2012 & \text { Q4 } & 8.4 & 9.8 & 1.9 \\ & \text { Q1 } & 8.2 & 9.8 & 1.5 \\ & \text { Q2 } & 8.0 & 9.6 & 1.8 \\ 2013 & \text { Q3 } & 7.9 & 9.6 & 1.8 \\ & \text { Q4 } & 7.8 & 9.8 & 1.3 \\ & \text { Q1 } & 7.9 & 9.6 & 0.8 \\ 2014 & \text { Q2 } & 7.7 & 9.6 & 1.0 \\ & \text { Q3 } & 7.6 & 9.3 & 0.7 \\ & \text { Q4 } & 7.2 & 9.6 & 0.9 \\ & \text { Q1 } & 6.8 & 9.3 & 1.1 \\ & \text { Q2 } & 6.3 & 9.4 & 0.5 \\ & \text { Q3 } & 6.0 & 8.5 & 1.2 \\ & \text { Q4 } & 5.7 & 8.0 & 1.8 \\ & \text { Q1 } & 5.6 & 7.4 & 2.4 \\ & \text { Q2 } & 5.6 & 7.4 & 2.9 \\ & \text { Q3 } & 5.3 & 6.4 & 2.6 \\ & \text { Q4 } & 5.1 & 6.5 & 2.1 \\ & \text { Q1 } & 5.1 & 6.3 & 2.4 \\ & \text { Q2 } & 4.9 & 6.2 & 2.3 \\ & \text { Q3 } & 4.9 & 5.5 & 2.4 \\ & \text { Q4 } & 4.8 & 5.5 & 2.6 \\ & \text { Q1 } & 4.6 & 5.3 & 1.8 \\ & \text { Q2 } & 4.4 & 5.5 & 2.1 \\ & \text { Q3 } & 4.3 & 5.0 & 2.2 \\ & \text { Q4 } & 4.3 & 4.9 & 2.5\end{array}$


Appendix 2. Monthly wage growth and the Unemployment rate

\begin{tabular}{|c|c|c|c|c|c|}
\hline & Unemployment & Wages & & Unemployment & Wages \\
\hline Mar-01 & 5.0 & 6.2 & Nov-04 & 4.7 & 4.9 \\
\hline Apr-01 & 4.9 & 6.3 & Dec-04 & 4.7 & 4.8 \\
\hline May-01 & 5.0 & 5.1 & Jan-05 & 4.8 & 4.8 \\
\hline Jun-01 & 5.0 & 5.5 & Feb-05 & 4.7 & 5.0 \\
\hline Jul-01 & 5.1 & 5.2 & Mar-05 & 4.7 & 4.9 \\
\hline Aug-01 & 5.1 & 5.2 & Apr-05 & 4.8 & 4.7 \\
\hline Sep-01 & 5.1 & 4.8 & May-05 & 4.8 & 4.3 \\
\hline Oct-01 & 5.1 & 4.7 & Jun-05 & 4.7 & 4.4 \\
\hline Nov-01 & 5.2 & 4.5 & Jul-05 & 4.7 & 4.6 \\
\hline Dec-01 & 5.2 & 4.1 & Aug-05 & 4.7 & 4.8 \\
\hline Jan-02 & 5.1 & 3.8 & Sep-05 & 4.9 & 4.8 \\
\hline Feb-02 & 5.2 & 3.3 & Oct-05 & 5.1 & 4.6 \\
\hline Mar-02 & 5.2 & 3.1 & Nov-05 & 5.1 & 4.3 \\
\hline Apr-02 & 5.2 & 3.1 & Dec-05 & 5.1 & 4.3 \\
\hline May-02 & 5.2 & 3.3 & Jan-06 & 5.2 & 4.3 \\
\hline Jun-02 & 5.2 & 3.7 & Feb-06 & 5.2 & 4.8 \\
\hline Jul-02 & 5.2 & 3.8 & Mar-06 & 5.3 & 5.3 \\
\hline Aug-02 & 5.3 & 3.5 & Apr-06 & 5.4 & 5.4 \\
\hline Sep-02 & 5.2 & 3.4 & May-06 & 5.5 & 4.9 \\
\hline Oct-02 & 5.2 & 3.0 & Jun-06 & 5.5 & 4.8 \\
\hline Nov-02 & 5.1 & 2.9 & Jul-06 & 5.5 & 4.9 \\
\hline Dec-02 & 5.0 & 2.7 & Aug-06 & 5.5 & 4.6 \\
\hline Jan-03 & 5.1 & 2.6 & Sep-06 & 5.5 & 3.9 \\
\hline Feb-03 & 5.2 & 2.4 & Oct-06 & 5.4 & 3.8 \\
\hline Mar-03 & 5.1 & 3.0 & Nov-06 & 5.5 & 3.9 \\
\hline Apr-03 & 5.0 & 3.1 & Dec-06 & 5.5 & 4.6 \\
\hline May-03 & 4.9 & 3.3 & Jan-07 & 5.5 & 5.5 \\
\hline Jun-03 & 5.1 & 2.7 & Feb-07 & 5.5 & 6.6 \\
\hline Jul-03 & 5.1 & 2.7 & Mar-07 & 5.5 & 6.3 \\
\hline Aug-03 & 5.0 & 2.9 & Apr-07 & 5.4 & 5.4 \\
\hline Sep-03 & 5.0 & 3.1 & Мay-07 & 5.4 & 4.5 \\
\hline Oct-03 & 4.9 & 3.5 & Jun-07 & 5.3 & 4.3 \\
\hline Nov-03 & 4.9 & 3.7 & Jul-07 & 5.3 & 4.5 \\
\hline Dec-03 & 4.8 & 3.9 & Aug-07 & 5.3 & 4.7 \\
\hline Jan-04 & 4.8 & 3.9 & Sep-07 & 5.2 & 5.1 \\
\hline Feb-04 & 4.8 & 3.9 & Oct-07 & 5.2 & 4.9 \\
\hline Mar-04 & 4.8 & 3.7 & Nov-07 & 5.2 & 4.7 \\
\hline Apr-04 & 4.8 & 3.7 & Dec-07 & 5.2 & 3.9 \\
\hline May-04 & 4.8 & 4.1 & Jan-08 & 5.2 & 4.0 \\
\hline Jun-04 & 4.8 & 4.3 & Feb-08 & 5.2 & 3.9 \\
\hline Jul-04 & 4.7 & 4.4 & Mar-08 & 5.3 & 4.5 \\
\hline Aug-04 & 4.7 & 4.4 & Apr-08 & 5.2 & 4.7 \\
\hline Sep-04 & 4.7 & 4.6 & May-08 & 5.4 & 4.6 \\
\hline
\end{tabular}




\begin{tabular}{|c|c|c|c|c|c|}
\hline Oct-04 & 4.7 & 4.7 & Jun-08 & 5.5 & 4.0 \\
\hline Jul-08 & 5.7 & 3.5 & Мay-12 & 8.0 & 1.4 \\
\hline Aug-08 & 5.9 & 3.2 & Jun-12 & 8.0 & 1.5 \\
\hline Sep-08 & 6.0 & 2.9 & Jul-12 & 7.9 & 1.4 \\
\hline Oct-08 & 6.2 & 3.0 & Aug-12 & 7.9 & 1.6 \\
\hline Nov-08 & 6.4 & 2.7 & Sep-12 & 7.9 & 1.8 \\
\hline Dec-08 & 6.5 & 2.7 & Oct-12 & 7.8 & 1.7 \\
\hline Jan-09 & 6.7 & 1.2 & Nov-12 & 7.8 & 1.5 \\
\hline Feb-09 & 7.1 & -1.5 & Dec-12 & 7.8 & 1.2 \\
\hline Mar-09 & 7.3 & -2.6 & Jan-13 & 8.0 & 1.3 \\
\hline Apr-09 & 7.6 & -1.8 & Feb-13 & 7.8 & 1.2 \\
\hline Маy-09 & 7.8 & 0.4 & Mar-13 & 7.8 & 0.6 \\
\hline Jun-09 & 7.9 & 1.0 & Apr-13 & 7.8 & 1.4 \\
\hline Jul-09 & 7.9 & 0.6 & Мay-13 & 7.7 & 1.6 \\
\hline Aug-09 & 7.8 & 0.6 & Jun-13 & 7.7 & 2.1 \\
\hline Sep-09 & 7.9 & 0.6 & Jul-13 & 7.7 & 1.1 \\
\hline Oct-09 & 7.8 & 0.6 & Aug-13 & 7.6 & 0.7 \\
\hline Nov-09 & 7.8 & 0.7 & Sep-13 & 7.4 & 0.7 \\
\hline Dec-09 & 7.7 & 0.7 & Oct-13 & 7.2 & 0.8 \\
\hline Jan-10 & 7.9 & 1.1 & Nov-13 & 7.2 & 0.8 \\
\hline Feb-10 & 8.0 & 2.6 & Dec-13 & 7.2 & 1.0 \\
\hline Mar-10 & 8.0 & 2.9 & Jan-14 & 6.9 & 1.3 \\
\hline Apr-10 & 7.9 & 2.8 & Feb-14 & 6.8 & 1.7 \\
\hline May-10 & 7.9 & 1.6 & Mar-14 & 6.6 & 1.8 \\
\hline Jun-10 & 7.8 & 1.6 & Apr-14 & 6.4 & 0.6 \\
\hline Jul-10 & 7.8 & 1.7 & May-14 & 6.3 & 0.0 \\
\hline Aug-10 & 7.8 & 1.8 & Jun-14 & 6.1 & -0.3 \\
\hline Sep-10 & 7.9 & 1.9 & Jul-14 & 6.0 & 0.5 \\
\hline Oct-10 & 7.9 & 2.1 & Aug-14 & 6.0 & 0.6 \\
\hline Nov-10 & 7.9 & 2.2 & Sep-14 & 6.0 & 0.9 \\
\hline Dec-10 & 7.9 & 2.2 & Oct-14 & 5.9 & 1.4 \\
\hline Jan-11 & 7.8 & 2.5 & Nov-14 & 5.7 & 1.8 \\
\hline Feb-11 & 7.8 & 2.6 & Dec-14 & 5.7 & 2.1 \\
\hline Mar-11 & 7.7 & 2.8 & Jan-15 & 5.6 & 2.0 \\
\hline Apr-11 & 7.8 & 2.5 & Feb-15 & 5.5 & 1.9 \\
\hline Мay-11 & 7.9 & 2.3 & Mar-15 & 5.5 & 2.4 \\
\hline Jun-11 & 8.0 & 2.4 & Apr-15 & 5.6 & 2.8 \\
\hline Jul-11 & 8.2 & 2.6 & May-15 & 5.6 & 3.2 \\
\hline Aug-11 & 8.3 & 2.6 & Jun-15 & 5.5 & 2.7 \\
\hline Sep-11 & 8.4 & 2.2 & Jul-15 & 5.4 & 3.0 \\
\hline Oct-11 & 8.5 & 1.9 & Aug-15 & 5.3 & 3.1 \\
\hline Nov-11 & 8.4 & 1.9 & Sep-15 & 5.2 & 3.1 \\
\hline Dec-11 & 8.3 & 1.9 & Oct-15 & 5.1 & 2.5 \\
\hline Jan-12 & 8.3 & 1.4 & Nov-15 & 5.1 & 2.1 \\
\hline Feb-12 & 8.2 & 1.0 & Dec-15 & 5.1 & 2.0 \\
\hline Mar-12 & 8.2 & 0.7 & Jan-16 & 5.1 & 2.3 \\
\hline
\end{tabular}




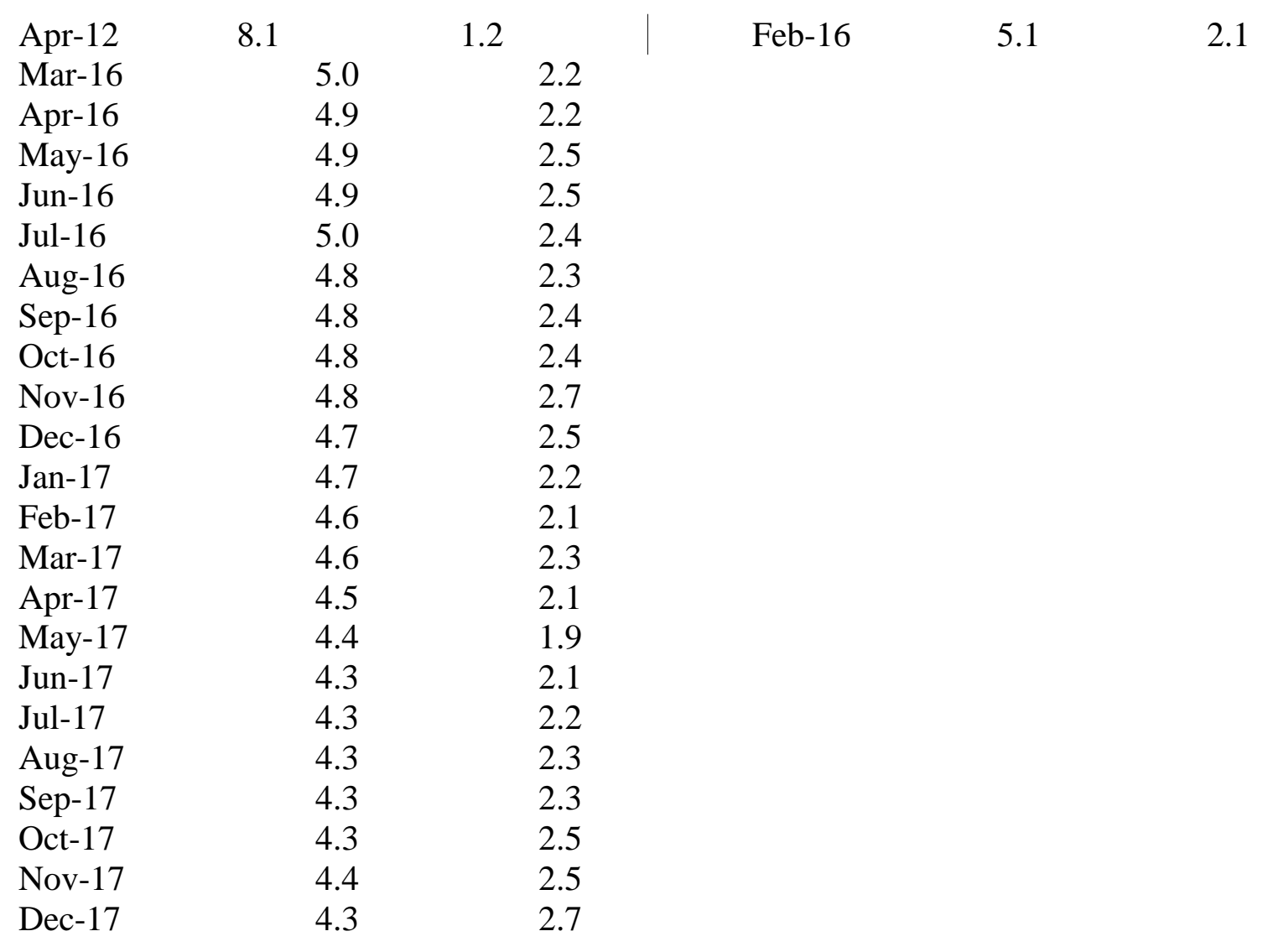

